\title{
Alternative Medicine in Modern France
}

\author{
MATTHEW RAMSEY*
}

Observers of the French medical scene may be struck by an apparent paradox. France is a major producer and consumer of nonconventional remedies, and by certain measures its use of alternative medicine ranks among the highest in Europe. Yet France stands out even among the countries of southern Europe, which have been less willing than those of the north to tolerate medical activities outside the norms of official biomedicine, for its institutionalized hostility to unsanctioned forms of medical practice. This situation has deep historical roots, which this essay seeks to reveal. Although it would be premature to attempt a full synthesis of a subject that remains largely unexplored, this account will offer a preliminary survey of the development of alternative medicine in what might seem an uncongenial environment. France was far less fertile soil than the United States or Germany for the growth of organized unconventional medical systems, movements, and institutions. Yet alternative medicine flourished there in different forms, and the very disadvantages under which it laboured contributed to its characteristic pugnacity and may even have enhanced its public appeal.

\section{Parallels and Intersections: In Search of a Vocabulary}

The title and opening paragraph of this essay beg a question as much as they describe a subject. Following the convention adopted for the symposium at the Wellcome Institute on which this special number of Medical History is based, "alternative medicine" will be used very broadly to refer to medicine practised by persons who lack official credentials and to beliefs that depart from the norms of biomedicine. Yet such a discursive move assumes what needs to be shown: how to make sense of the divergent beliefs and practices relating to health and disease in societies in which Western biomedicine has won special legal recognition and controls the lion's share of resources devoted to health care. How we write about this question is an important part of the subject itself. The very terms used to name it are notoriously unstable and may say as much about those who employ them as about the elusive object they are meant to describe.

This essay begins, then, with a discussion of language, concepts, and approaches: English and French terminology; different ways of thinking about medical pluralism; and distinctive features of the French literature and of the literature on the French experience, which are not, of course, the same thing. The objective is not to identify the single right word, idea, or method, but, rather, to provide a framework in which to address an Anglophone audience about two centuries of French history. Readers who prefer a more

\footnotetext{
* Professor Matthew Ramsey, Department of

History, Vanderbilt University, Nashville, TN 37235, USA.
} 
direct itinerary should feel free to skip to the section below entitled 'Contours of the French Experience'.

When we write about "alternative medicine", we are positing a dichotomy between two domains, seen from the perspective of one of them-let us call them insider and outsider medicine-and saying something about the nature of outsider medicine and the relationship between the two. We do the same when we employ each apparent synonym or near-synonym-“unorthodox", “irregular", "fringe", "vernacular", "popular", "unconventional", "unofficial", "complementary", "integrative", and the rest. All these terms define beliefs and behaviours against the standard of insider medicine, although at the same time each reflects a search for semantic neutrality: we are a long way from "quackery", "charlatanism", "superstitions", and "popular medical errors", but also from "natural medicine" and kindred expressions.

Alternative medicine and related terms are not, to be sure, entirely value-free. Unorthodox, irregular, and fringe are mildly pejorative, alternative and complementary, distinctly respectful. Nor are they in other respects entirely interchangeable. The widespread use of "alternative medicine" in English may have been the product of a particular historical moment. In British and to some extent American usage, "complementary" has been gaining currency, displacing or sometimes accompanying "alternative". In the US, the Office of Alternative Medicine of the National Institutes of Health adopted the portmanteau label "complementary and alternative medicine", or CAM, and was recently renamed the National Center for Complementary and Alternative Medicine. The new convention conveys a different normative message. Alternative suggests that one is leaving the high road of official medicine to follow another path to health, even if not all practitioners and very few patients forsake doctors and repudiate official medicine; it may connote deliberate defiance of convention, as in "alternative culture". Complementary implies that biomedicine can gain something by borrowing from other medical traditions, and that physicians and non-physician practitioners should cooperate rather than compete. In the European Parliament, a group dedicated to recognizing and standardizing the different forms of medical practice throughout the European Union has proposed assessing unconventional therapies and dividing the safe and effective ones into complementary treatments, which can supplement conventional methods, and alternative treatments, which can replace them. ${ }^{1}$ The effect of this strategy would be to blur the distinction between conventional and unconventional and draw a new boundary between valid medicine, now marvellously pluralistic, and mere junk. Such an approach is unlikely to win widespread acceptance any time soon, but it nicely illustrates the shifting semantic freight carried by the labels we apply to medical practices and beliefs.

In French, although the concept of an "official" medicine and science was well established by the middle of the nineteenth century, ${ }^{2}$ it has proved harder to find a

\footnotetext{
${ }^{1}$ Committee on the Environment, Public Health and Consumer Protection, 'Report on the status of non-conventional medicine', 6 March 1997, http://www.europarl.eu.int/dgl/a4/en/a4-97/a4-OC (all citations to the World Wide Web were current as of October 1998).
}

\footnotetext{
${ }^{2}$ See, for example, the comment by the Swiss writer H-F Amiel that his experience with walnut water "me confirme dans ma défiance des remèdes minéraux et dans ma circonspection avec la médecine officielle", Journal de l'année 1866, Paris, L Bopp, 1866 (reprinted Paris, Gallimard, 1959),
} 
common designation for the not-official. One occasionally encounters the borrowed expressions les médecines alternatives, complémentaires, and non conventionnelles, almost always in the plural, though they remain far less common than their English equivalents, or die alternative Medizin and die unkonventionnelle Heilweisen in German. The more common term at least since the 1960s has been les médecines parallèles. It is a close equivalent to alternative medicine, except that the plural suggests multiple divergences from a unitary core, and that the word parallele, which roughly means unofficial (as in la police parallele), carries overtones of the illicit and clandestine. The expression les médecines différentes, employed in some government publications, has not caught on. Sympathizers, however, are more likely to refer to les médecines douces, the common term for healing practices represented as non-technological, noninvasive, and natural, and a rough synonym of les médecines naturelles; they are thought to be friendly to the body in the way that les technologies douces are friendly to the environment. These expressions all refer to particular medical practices and beliefs. Militant practitioners of alternative medicine have tended to describe their activities collectively as la médecine libre. This expression, which appears to be less common now than it was a generation ago, is used in the singular and refers to medicine that is "free" in the sense that it is practised outside the zone of regulation. ${ }^{3}$

All these labels-in French as in English-are contested. Any dichotomy fails to capture the many ways in which the different forms of medicine intersect; Geneviève Paicheler, a sociologist at CERMES (Centre de recherche: Médecine, maladie et sciences sociales), has suggested that we might do better to write about "perpendicular" rather than parallel medicines. ${ }^{4}$ Nor, of course, can any dichotomy capture the bewildering variety of medical practices. For these reasons, even studies that begin with a careful critical discussion of terms and concepts rarely arrive at a consistent nomenclature that can be appropriated by other scholars. One of the most sophisticated recent publications dealing with the American scene uses "alternative medicine" in the subtitle, expresses a preference for "vernacular medicine" in the text, and proceeds to use a variety of other terms without comment where they seem to fit the context. ${ }^{5}$

This essay will be similarly pragmatic in its use of labels. Apart from "alternative medicine", the common coin of the Wellcome Institute conference, it will employ three other terms in particular contexts; none should be taken as reifying beliefs and practices into a coherent entity. "Medical outsiders" will refer to practitioners who do not have a

p. 345. Cf. the description by the French magnétiseur L-P Mongruel of his ongoing struggle with "la science officielle" in Le Magnétisme militant: origine et histoire des luttes, progrès et conquêtes de la science; le somnambulisme aux prises avec les corps savants calomnié, traduit devant la haute magistrature et défendu par les sommités du barreau; affaire de la Sibylle moderne: instruction, débats, jugement, infirmation, pourvoi, Paris, the author, 1851, unpaginated preface. Such expressions tend, of course, to be used by outsiders, who are also often detractors; insiders commonly refer to official medicine as "medicine".

${ }^{3}$ To confuse matters, la médecine libre is also sometimes the equivalent of la médecine libérale, in the sense of private practice-an analogous but distinct usage.

${ }^{4}$ Paicheler, 'Médecines parallèles ou perpendiculaires', afterword to Yves Barel and Marie Butel, Les Médecines parallèles: quelques lignes de force, for the Ministère des Affaires Sociales et de l'Emploi, Centre de rencontres transdisciplinaires, and Centre d'études des pratiques sociales, Paris, La Documentation française, 1988, pp. 286-90.

${ }^{5}$ Bonnie Blair O'Connor, Healing traditions: alternative medicine and the health professions, Philadelphia, University of Pennsylvania Press, 1995. 


\section{Alternative Medicine in Modern France}

place in the official institutional and professional structures of modern medicine; "nonstandard medicine(s)", to practices and beliefs outside the mainstream of official medicine, whether associated with medical outsiders or with licensed practitioners; and "alternative medicine in the strong sense" or "counterhegemonic medicine" to institutions, practices, and beliefs predicated on conscious opposition to biomedicine and medical insiders.

It is important to recognize the ways in which these categories, too, are problematic or historically contingent. Alternative medicine, even in the weakest sense, presupposes the existence of a powerful, if not necessarily hegemonic, official medicine, and of recognizable boundaries between official and nonofficial. Yet the concept of "official medicine" itself is not so self-evident as at first appears. We can perhaps agree in recognizing it as a domain in which the activities of certified expert practitioners of medicine intersect with the activities of certified experts in the production of scientific knowledge. But this is very abstract, and the key question of how, historically, such a domain was constituted in different social and political contexts has not received the sort of attention that scholars have devoted to two highly controverted questions with which it is closely connected, the development of the modern medical profession and the construction of scientific authority.

Moreover, the notion of official medicine as a distinctive modern historical phenomenon is open to criticism from two perspectives. The first objection points to the long pedigree of learned medicine and its special prerogatives; as Michael McVaugh has shown, the perception that university-trained physicians deserved greater confidence than their rivals can be traced to the late Middle Ages. ${ }^{6}$ Well before the nineteenth century, faculties and academies endorsed some approaches and damned others. The second objection takes issue with treating biomedicine as a free-standing monolith. The medical profession has been riven by internal disputes over such fundamental questions as the aetiology of disease, and it has often been hard to draw a clear external boundary between professionals and laity battling it out in the medical marketplace and the Habermasian public sphere. If we apply a loose criterion, official medicine recedes into the distant past; if we apply a very strict one, it seems to disappear.

These questions cannot be resolved here, but the argument of this essay depends on a particular way of addressing them which deserves a brief comment. Official medicine is a social and cultural construction, created in part by alliances with the state but also through the rhetorical strategy of promoting the legitimacy and credibility of certain practitioners, practices, and beliefs-and undermining those of others-within the public sphere. ${ }^{7}$ This is a dynamic process, and official medicine should not be seen as a static thing with certain inherent characteristics-as science-based medicine, for example, or the medicine of university graduates. Nor have the outcomes of this process been uniform in all places. Nevertheless, each Western society, with some differences in timing, came to recognize what by the mid-nineteenth century was called la médecine officielle in

\footnotetext{
${ }^{6}$ Michael R McVaugh, Medicine before the plague: practitioners and their patients in the crown of Aragon, 1285-1345, Cambridge University Press, 1993.

${ }^{7}$ This was a central point, for example, of
}

Lucinda McCray Beier's paper, 'The creation of the medical fringe, 1500-1700', meeting on 'Fringe medicine and popular belief', Sheffield City Polytechnic, 1981; see Society for the Social History of Medicine, Bulletin, 1981, 29: 29-32. 
France-roughly, the medicine of doctors, science, and the government. In earlier periods, the concept of alternative medicine loses its force; Roy Porter's warning about the anachronism of writing about fringe medicine "before the fringe" makes a compelling point. ${ }^{8}$ With the emergence of a powerful official medicine, it becomes increasingly difficult for all concerned, whether physicians or medical outsiders, patients or government officials, not to see alternative medicine as in some sense oppositional-even if it is based on beliefs and practices that are not represented as counterhegemonic and may, indeed, overlap official medicine to a considerable extent.

Still, some forms of alternative medicine are more clearly associated than others with explicitly counterhegemonic programmes; the nature of these claims will be one of the central questions addressed in this essay. For the purposes of analysis it will be helpful to distinguish three sorts of contentions. The first challenges professional monopoly and justifies the right of medical outsiders to practise medicine on one or more of several possible grounds: that a particular individual possesses a special skill; that open competition fosters scientific progress; or that the freedom to engage in an occupation or to consult the practitioner of one's choosing is a fundamental right. The second advocates a type of nonstandard medicine or a therapy that has failed to win official recognition, despite what its defenders consider abundant evidence of its efficacy. Such therapeutic approaches sometimes depend on a nonstandard model of physiology and pathology, but not necessarily; for example, many owners of what the French called "secret remedies" claimed only to know from experience that their formula cured disease, without invoking a distinctive medical system. The third claim is a stronger form of the second, contesting the overarching models of biomedicine and the scientific method and the uses to which they are put in industrial societies. The beliefs that people hold about health and disease often intersect with other fundamental beliefs about the world in which they live. Among the many extramedical associations of alternative medicine, two broad features stand out, which might be labelled cultural and political. The first is sometimes called antipositivism, though that term needs to be unpacked and is in a sense a misnomer, since counterhegemonic medicine was less often antiscientific than anti-materialist and was arguably consistent with the spiritual and metaphysical components of positivism as understood by Auguste Comte and some of his disciples. The association of alternative medicine with political radicalism is well known, particularly for the nineteenth century; its links to political reaction are sometimes forgotten by historians whose own sympathies tend to run the other way. This is a case in which les extrêmes se touchent.

Are some counterhegemonic medicines, then, best seen as the manifestation of more general developments in the larger society, or as the product of a coherent alternative world view? Roger Cooter has raised this question with particular force in an essay entitled 'Alternative medicine, alternative cosmology'. ${ }^{9}$ In a searching and very subtle analysis of orthodox and heterodox modes of discourse in the nineteenth century, he breaks down the dichotomy between mechanistic orthodoxy and vitalist or spiritualist heterodoxy in several

\footnotetext{
${ }^{8}$ Porter, 'Before the fringe: "quackery" and the eighteenth-century medical market,' in Roger Cooter (ed.), Studies in the history of alternative medicine, New York, St Martin's Press, 1988, pp. 1-27.

${ }^{9}$ Cooter, in ibid., pp. 63-78. The title of an
}

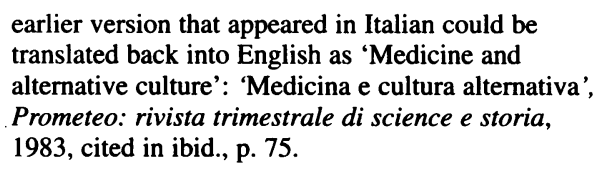

earlier version that appeared in Italian could be translated back into English as 'Medicine and alternative culture': 'Medicina e cultura alternativa', Prometeo: rivista trimestrale di science e storia, 1983, cited in ibid., p. 75. 
ways, arguing, among other points, that the Victorians did not see alternative medicine as explicitly antiscientistic; that the various heterodoxies were too gloriously eclectic, too theoretically inchoate, and, increasingly, too deferential to medical science to constitute a coherent alternative to scientism; and that orthodox medicine, for much of his period, was not itself of sufficient metaphysical purity to serve as the counterpoint to a putatively antipositivist alternative medicine. Yet the rest of his analysis, and the bulk of his examples, support a view not of alternative medicine as a consistently antipositivist movement, but of antipositivism as a powerful force within alternative medicine.

Although few forms of alternative medicine could be called antiscientific, the opposition to scientistic ideology and reductive materialism has been widespread. In some societies, the association with religion, spiritualism, and an anti-materialist metaphysics has been overwhelming. The US is perhaps the best illustration, with the major exception in the nineteenth century of Thomsonianism - an essentially naturalistic system based on the properties of plant remedies-and of chiropractic and the mature "materialized" form of osteopathy. ${ }^{10}$ Whether or not they explicitly evoke the concept of soul, spirit, or nonmaterial forces, counterhegemonic medicines typically claim to restore the personhood putatively denied by modern biomedicine. Those that purport to derive their efficacy from forces inaccessible to conventional science promise not only to restore health but also to recover a realm of human experience stunted or suppressed by the dominance of the modern scientific world view.

\section{Recounting the French Case: Competing Voices}

How these questions worked themselves out in the French context is a problem on which much work remains to be done, particularly for the later nineteenth and twentieth centuries. A vast antiquarian literature has accumulated on medical outsiders and nonstandard medical practices, but alternative medicine has attracted less systematic attention from historians of France than it has, for example, among historians of medicine working on Britain and the US, and it has tended to come from specialists on French medical history in the English-speaking world. For Anglo-American medicine, we have the three seminal collections of essays published in 1987 and 1988, edited by W F Bynum and Roy Porter, Roger Cooter, and Norman Gevitz, which helped to define an initial problematic for the subfield. ${ }^{11}$ In France, the major specialists on the social history of medicine in the nineteenth century, most prominently Olivier Faure and the late Jacques Léonard, have given significant attention to medical outsiders. ${ }^{12}$ In addition, a few recent

\footnotetext{
${ }^{10}$ Robert C Fuller, Alternative medicine and American religious life, New York and Oxford, Oxford University Press, 1995.

${ }^{11} \mathrm{~W}$ F Bynum and Roy Porter (eds), Medical fringe \& medical orthodoxy, 1750-1850, London, Croom Helm, 1987; Cooter (ed.), op. cit., note 8 above; Norman Gevitz (ed.), Other healers: unorthodox medicine in America, Baltimore, Johns Hopkins University Press, 1988.

${ }^{2}$ See their massive state doctoral theses and the publications derived from them. Léonard, Les Médecins de l'Ouest au XIX ${ }^{e}$ siècle (thesis,
}

\author{
Université Paris IV, 1976), Lille, Atelier reproduction \\ des thèses, 1978; idem, La Médecine entre les \\ pouvoirs et les savoirs: histoire intellectuelle et \\ politique de la médecine française au XIX $X^{e}$ siècle, \\ Paris, Aubier-Montaigne, 1981; idem, 'Les \\ Guérisseurs en France au XIX ${ }^{\mathrm{e}}$ siècle', Revue \\ d'histoire moderne et contemporaine, 1980, 27 : \\ 501-16. Faure, 'La Médicalisation de la société dans \\ la région lyonnaise au XIX ${ }^{\mathbf{e}}$ siècle', thesis, \\ Université Lumière-Lyon II, 1989. Idem, Histoire \\ sociale de la médecine (XVIII $-X X^{e}$ siècles), Paris, \\ Anthropos, 1994.
}


publications in social and cultural history have dealt with alternative medicine as part of some larger topic. An outstanding example is Nicole Edelman's study of the women known as somnambules magnétiques; it was believed that the visions they experienced while in a "magnetic" trance enabled them to diagnose disease and prescribe remedies, as well as to perform feats of divination. ${ }^{13}$ But there are no real French equivalents to the three Anglo-American collections cited earlier, or to the series of historical studies by James Harvey Young on American patent medicines, ${ }^{14}$ or to the important recent survey of the history of modern German alternative medicine by Robert Jütte. ${ }^{15}$

Alternative medicine, however, has been much more extensively studied from other vantage points, as can be seen, for example, in an oft-cited special number of the journal Autrement published in 1978; the contributors, mainly sociologists and anthropologists, included three historians, though all were specialists on periods before $1800 .{ }^{16}$ In the late 1980s, around the time of the publication of the Bynum/Porter, Cooter, and Gevitz collections, two synoptic works appeared in French. A leading medical anthropologist, François Laplantine, in collaboration with a practising psychiatrist, produced an accessible but thoughtful overview of alternative medicine for the popular 'Que sais-je?' series, and the Ministry of Social Affairs and Employment, which had been led by a devotee of les médecines douces, published a thorough overview of contemporary alternative medicine, with some attention to the historical background. ${ }^{17}$ The former publication represents a particularly well developed subdiscipline in France, largely overlapping what has been institutionalized in the Anglo-American world as medical folklore studies. The latter, essentially a catalogue of unconventional medical systems, is similar to guides published by government agencies and professional bodies elsewhere. France also has a long and still living tradition of surveys of alternative medicine written by individual physicians, often based on the thesis for the medical doctorate. ${ }^{18}$

Some of the ethnographic work comes out of the tradition of systematic collecting given academic respectability by Arnold van Gennep in his multi-volume work on French folklore. ${ }^{19}$ Much recent scholarship, though, like van Gennep's own career, blurs the distinction between ethnology and folklore, and borrows from the theoretical contributions of cultural anthropology. Students of nonstandard medical practices in France have also drawn increasingly on urban anthropology and moved beyond the

\footnotetext{
${ }^{13}$ Edelman, Voyantes, guérisseuses et visionnaires en France, 1785-1914, Paris, Albin Michel, 1995.

14 James Harvey Young, The toadstool millionaires: a social history of patent medicines in America before federal regulation (1961), The medical messiahs: a social history of health quackery in twentieth-century America (1967), and American health quackery: collected essays (1992), all published by Princeton University Press.

15 Jütte, Geschichte der alternativen Medizin: von der Volksmedizin zu den unkonventionnellen Therapien von heute, Munich, Verlag C H Beck, 1996.

${ }^{16}$ Autrement, no. 15, September 1978, Panseurs de secrets et de douleurs. Cf. no. 9, May 1977, Francs-tireurs de la médecine.

${ }^{17}$ François Laplantine and Paul-Louis Rabeyron,
}

Les Médecines parallèles, Paris, Presses

Universitaires de France, 1987; Barel and Butel, op. cit., note 4 above.

${ }^{18}$ See, for example, Françoise Thévenet, Répertoire des médecines parallèles en France, Paris, Dervy Livres, 1987, based on her medical thesis.

${ }^{19}$ Manuel de folklore français contemporain, Paris, Picard, 1937- . See Nicole Belmont, Arnold van Gennep: the creator of French ethnography, trans. Derek Coltman, University of Chicago Press, 1979, and Rosemary Lévy-Zumwalt, The enigma of Arnold van Gennep (1873-1957): master of French folklore and hermit of Bourg-la-Reine, FF Communications no. 241, Helsinki, Academia Scientiarum Fennica, 1988. 
conception of folklore as the study of almost timeless peasant traditions, even if they sometimes cling to a distinction between "traditional" and "modern" healers. ${ }^{20}$ Some of the most influential contributions of the last several decades have.treated all forms of nonstandard medical practices and beliefs and have attempted to trace their historical development. The still useful synthetic study of "popular medicine" by Marcelle Bouteiller, originally published in 1966, is largely concerned with the transformation of alternative medicine in a modernizing society. ${ }^{21}$ Françoise Loux, of the Musée des Arts et Traditions Populaires, has drawn extensively on historical materials, including archival sources. ${ }^{22}$ Laplantine brings to his work on French alternative medicine not only the perspective of his training in cultural anthropology but also a strong historical consciousness and narrative impulse. His study of French and Brazilian spiritism, written in collaboration with Marion Aubrée, is primarily a cross-national history of a cultural and social movement with an important medical dimension. ${ }^{23}$ Much of this work conveys at least a certain ethnological sympathy for its subject, and occasionally much more; when the psychiatrist-turned-ethnologist Jeanne Favret conducted her field work on counterwitchcraft practices in the bocage region of Western France, she found after a time that she had become a part of the world she was studying, in which words could be dangerous. ${ }^{24}$ There are, however, fewer sociological and ethnological studies in France than in the UK that are marked both by high standards of scholarship and a clear commitment to promoting alternative medicine or medical pluralism as a programme-as one sees, for example, in the work of Mike Saks or Ursula Sharma. ${ }^{25}$

In addition to these ethnological and sociological studies, the student of French alternative medicine can turn to a profusion of journalistic accounts, partisan publications by adherents and antagonists of nonstandard medicines, and the many discussions of the development of counterhegemonic movements that can be found in the alternative medical literature itself. ${ }^{26}$ The popular press has long included an abundance of periodicals devoted to disseminating alternative approaches to health maintenance and medicine, with titles such as Médecines nouvelles, Médecines douces, and SantéMagazine. Many of these publications are listed in the eight-page bibliography of the study from the Ministry of Social Affairs, which draws no distinction between primary and secondary sources-not an easy differentiation to make in this context.

In all of this literature, there is little that is distinctively French, except perhaps for the strong tradition of mingling folklore and ethnology. The relative underdevelopment of

\footnotetext{
${ }^{20}$ See, for example, François Laplantine, $L a$ Médecine populaire des campagnes françaises aujourd'hui, Paris, Jean-Pierre Delarge, 1978.

${ }^{21}$ Bouteiller, Médecine populaire d'hier et d'aujourd'hui, Paris, Maisonneuve et Larose, 1987.

${ }^{22}$ See Françoise Loux and Philippe Richard, Sagesses du corps: la santé et la maladie dans les proverbes français, Paris, Maisonneuve et Larose, 1978.

${ }^{23}$ Aubrée and Laplantine, La Table, le livre et les esprits: naissance, évolution et actualité du mouvement social spirite entre France et Brésil, Paris, J C Lattes, 1990.

24 Jeanne Favret-Saada, Deadly words: witchcraft
}

in the bocage, trans. Catherine Cullen, Cambridge University Press, 1980.

${ }^{25}$ Mike Saks (ed.), Alternative medicine in Britain, Oxford, Clarendon Press, 1991. Ursula Sharma, Complementary medicine today: practitioners and patients, London and New York, Tavistock/Routledge, 1992; idem and Sarah Cant (eds), Complementary and alternative medicines: knowledge in practice, London and New York, Free Association Books, 1996.

${ }^{26}$ For one example among many, see Pierre Neuville, Les Meilleurs Guerisseurs de France, 2 vols, Paris, Agence parisienne de distribution, 1950-52. 


\section{Matthew Ramsey}

historical studies, however, arguably is. The reasons are at least partly institutional-the marginality of medical history itself as an academic discipline. ${ }^{27}$ Now that the common medical curriculum for the European Union calls for including medical history as an option we can expect it to develop as a teaching subject, but there is no obvious impetus for new scholarship. ${ }^{28}$ Nor is there a major independent institute for medical history, though there are smaller research units and individual scholars based in, or affiliated with, larger organizations-INSERM, the CNRS (Centre National de la Recherche Scientifique), and the École des Hautes Études en Sciences Sociales. ${ }^{29}$ The institution with the strongest commitment to the social history of medicine and the history of alternative medicine is the Centre Pierre Léon d'Histoire Économique et Sociale in Lyons, where Olivier Faure and his collaborators have done pioneering work on French homoeopathy ${ }^{30}$ At Créteil in the Paris suburbs, the Groupe de Recherche en Histoire Sociale et Épistémologie de la Médecine, of the University of Paris XII, has also sponsored work on the history of alternative medicine, including conferences on medical popularization. ${ }^{31}$ Funding is very limited, with no private-sector equivalent to the Wellcome Trust or the Robert Bosch Stiftung in Germany. The work on homoeopathy was supported by the Boiron pharmaceutical firm, which is based in Lyons and is the foremost producer of homoeopathic remedies. ${ }^{32}$ The Fondation Mérieux for biomedical research, which draws its funds from the Mérieux Institute, the world's leading vaccine manufacturer, organizes conferences on medical history (generally in collaboration with the Wellcome Trust and the Institut Louis-Jeantet d'Histoire de la Médecine, Geneva); a major interdisciplinary colloquium on therapeutics in November 1997 gave some attention to alternative medicine. The foundation, however, does not subsidize medical historical research. ${ }^{33}$

\footnotetext{
${ }^{27}$ The only medical faculty that is a serious research centre in the field is the one at Strasbourg, which houses the Centre Éuropéen d'Histoire de la Médecine, directed by Claude Debru, and serves as the seat of the European Association for the History of Medicine and Health. The Centre is oriented primarily toward the history and philosophy of biomedicine. See Robert Jütte (ed.), Institutes for the history of medicine and health in Europe: a guide, Sheffield, European Association for the History of Medicine and Health Publications, 1997, pp. 3-9.

${ }^{28}$ See the manual produced in response to the new French medical curriculum: Danielle Gourevitch (ed.), Histoire de la médecine: leçons méthodologiques, Paris, Ellipses, 1995. Cf. Yves Ferroul, Antoine Drizenko, and Dominique Boury, Médecin et médecine: manuel d'introduction à l'étude de l'histoire de la médecine, Paris, Honoré Champion, 1997.

${ }^{29}$ The staff at CERMES includes the historians of public health Lion Murard and Patrick Zylberman; at INSERM there is an interdisciplinary group headed by Patrice Pinell; and within the EHESS, Jean-Pierre Goubert and Patrice Bourdelais, of the Centre de Recherches Historiques, have directed seminars and workshops on topics relating to medical history. Pierre Darmon, a directeur d'études at the CNRS,
}

has also been a particularly prolific and versatile historian of modern medicine.

${ }^{30}$ See the essays in Faure (ed.), Praticiens, patients et militants de l'homéopathie aux XIX et $X X^{e}$ siècles (1800-1940), Lyons, Éditions Boiron/Presses Universitaires de Lyon, 1992.

${ }^{31}$ See Jacques Poirier and Claude Langlois, Raspail et la vulgarisation médicale, Paris, Vrin, 1988; idem, Médecine et vulgarisation (XVIIle-XXe siècles), Créteil, Université Paris XII, 1991; and Daniel Teysseire (ed.), La Médecine du peuple, de Tissot à Raspail (1750-1850), Créteil, Conseil Général du Valde-Marne/Archives Départementales, 1995.

32 On the research project involving the Université Lumière-Lyon II, the Centre Pierre Léon, and the Boiron company, see Faure, Le Débat autour de l'homéopathie en France, 1830-1870, Collection du caducée, n. p., Boiron, 1990.

33 'Les thérapeutiques: savoirs et usages', SaintJulien, Musée Claude-Bernard-Fondation Marcel Mérieux, and Lyons, Centre Pierre Léon d'Histoire Économique et Sociale, Université Lumière-Lyon II, 13-15 November 1997. On the Fondation Mérieux, Boiron, and the special position of the Lyons pharmaceutical industry, see Robin Madell, 'Lyon: a center of its own', Pharmaceutical Executive, 1996, 16: 68-74. 


\section{Contours of the French Experience: Monopoly and Militancy}

The relative thinness of the historiography may also reflect the long-standing marginality of French alternative medicine itself. In a world moving toward medical pluralism, France often appears as a redoubt for the dualist model, in particular contrast to the US, Germany, Austria, the Scandinavian countries, and the UK. In England, the Medical Act of 1983 maintained a long tradition of protecting official titles and restricting certain privileges, such as government appointments, to registered practitioners, while leaving those without official qualifications free to practise medicine. The latter are subject only to the common law-essentially responsibility for malpractice-and restrictions on the use of some therapies and the treatment of particular conditions, such as venereal disease. ${ }^{34}$ In the Netherlands, legislation that took effect in 1997 introduced a similar regime, with the possibility of government prosecution for causing harm. In France, there have been isolated moves to liberalize the regulatory regime-an ill-fated bill introduced by five deputies in the National Assembly in 1963 would have legalized the activities of persons with a known healing gift ${ }^{35}$ - and the zeal of prosecutors appears to have diminished in the last decade. But the most recent revision of the Public Health Code, in the summer of 1996, maintained a strong ban on unqualified practice, which is subject to a fine of 60,000 francs and/or a three-month prison term, with the penalties doubled for a second offence (art. L.376).

The relationship between official and nonstandard medicine in France is more complex than the legal status of medical outsiders. ${ }^{36}$ Physicians enjoy considerable freedom in treatment decisions, and the social security system pays for nonstandard remedies when a medical doctor has prescribed them; chiropractic manipulation by a physician is similarly reimbursable. Homoeopathy, acupuncture and osteopathy are even taught in some medical faculties. The University of Paris-Nord at Bobigny pioneered a Diplôme universitaire de médecines naturelles (DUMENAT). A consortium of faculties offers an inter-university diploma in acupuncture, available only to medical doctors. ${ }^{37}$ Physicians can also study manual medicine (a catchall term for osteopathy, chiropractic, spondylotherapy, etiopathy, and related practices) at fifteen medical faculties; they confer an inter-university diploma in manual medicine/osteopathy, created in 1997 to replace an earlier university diploma in orthopaedic medicine and manual therapeutics. ${ }^{38}$ But the government has not recognized separate professions or institutions for alternative medicine or created a state doctorate distinct from the medical degree. A decree of 6 January 1962 held that chiropractic

\footnotetext{
${ }^{34}$ See Stephen Gordon, 'The regulation of complementary medicine', Consumer Policy Review, 1997, 7: 65-9. For the background, see the essays in Terry Johnson, Gerry Larkin, and Mike Saks (eds), Health professions and the state in Europe, London and New York, Routledge, 1995; on the UK: ch. 3, Larkin, 'State control and the health professions in the United Kingdom', and ch. 7, Saks, 'The changing response of the medical profession to alternative medicine in Britain'.

${ }^{35}$ Léon Gruart, Médecins et guérisseurs, Paris, Hachette, 1966, pp. 87, 109.

${ }^{36}$ See Françoise Bouchayer, 'Alternative medicines: a general approach to the French
}

situation', in George Lewith and David Aldridge (eds), Complementary medicine and the European Community, Saffron Walden, C W Daniel Co. Ltd, 1991, pp. 45-60.

${ }^{37}$ Universities of Lyons I, Aix-Marseille II, Montpellier I, Nice, Paris-Nord (Bobigny), Strasbourg I, Lille, Nantes, Victor SegalenBordeaux II, and Seville (Spain); http://www.ubordeaux 2.fr.

${ }^{38} \mathrm{http}: / /$ www.csmf.org/CSMFUMESPE/ UMESPEsnmof.htm. The participating faculties are Paris VI, Paris XIII (Bobigny), Marseilles, Lyons, Rennes, Toulouse, Grenoble, Strasbourg, Montpellier, Saint-Étienne, Lille, Dijon, and Reims. 


\section{Matthew Ramsey}

constituted a "medical act", which in effect means that non-physicians who practise it, including holders of a foreign doctorate in chiropractic, are guilty of illegal medical practice. The few occupations recently accorded legal standing, such as masseurskinesitherapists, ergotherapists, and the distinctively French specialists in psychomotor therapy (psychomotriciens), either are medical auxiliaries clearly subordinated to physicians or are barred from supplying their services for therapeutic purposes. France lies at the opposite end of the spectrum from the German model of dual regulation, which allows what Paul Unschuld has characterized as the "structured coexistence" of conventionally trained physicians with licensed Heilpraktiker trained in a great variety of nonstandard methods. ${ }^{39}$ A situation similar to the German one exists in many American states. In England, the "unstructured coexistence" of two medical worlds is giving way to new regulated sectors, starting with the recent statutory recognition of chiropractic and osteopathy. Most forms of unconventional practice remain outside the pale, however, and the question of the relationship to the National Health Service remains to be resolved, though the NHS does support homoeopathic therapy when patients request it.

Nor have alternative medicines in France achieved the sort of legitimacy symbolized by the Office of Alternative Medicine established at the US National Institutes of Health in 1993, by research and clinical centres at major American and Canadian institutions, such as the Tzu Chi Institute for Complementary and Alternative Medicine, opened at Vancouver Hospital in 1996, or, in the UK, by the Centre for Complementary Medicine at Exeter University, which receives funds from the Department of Health. ${ }^{40}$ In 1982 and again in 1986, the French government created a special commission to study the question and make recommendations for a new policy on alternative medicine. The first group, chaired by a physician-cum-acupuncturist named Niboyet, expressed scepticism about most forms of nonstandard medicine but did suggest that homoeopathy, acupuncture and manual medicine should be taught in the medical faculties. The second, which brought together clinicians, researchers, and representatives of patient groups, benefited from the sympathy for alternative medicine evinced by President Mitterrand's minister for social affairs, Georgina Dufoix, now best known as one of the defendants in the case of the HIVcontaminated blood. It underscored the widespread use of alternative therapies and the range of perspectives on the question, of which the orthodox medical profession represented only one. ${ }^{41}$ In 1985 Dufoix persuaded the INSERM to undertake controlled

\footnotetext{
${ }^{39}$ Paul U Unschuld, 'The issue of structured coexistence of scientific and alternative medical systems: a comparison of East and West German legislation', Soc. Sci. Med, 1980, 14B: 15-24.

${ }^{40}$ On the American OAM, see James Harvey Young, 'The development of the Office of Alternative Medicine in the National Institutes of Health, 1991-1996', Bull. Hist. Med., 1998, 72: 279-98, and US National Institutes of Health, Alternative medicine: expanding medical horizons: $a$ report to the National Institutes of Health on alternative medical systems and practices in the United States, Second Workshop on Alternative Medicine, 1992, Chantilly, VA, [NIH publication no. 94-066], Washington, DC, US Superintendent of Documents, 1995. Another indication of the effort to co-opt alternative medicine
}

\author{
is a special number of $J A M A$ devoted entirely to \\ assessments of alternative therapies: 280 , no. 18,11 \\ November 1998. For the recent shift in official \\ attitudes in the UK, see British Medical Association, \\ Complementary medicine: new approaches to good \\ practice, Oxford University Press, 1993. \\ ${ }^{41}$ Jacques-Émile-Henri Niboyet, Rapport sur \\ certaines techniques de soins ne faisant pas l'objet \\ d'un enseignement organisé au niveau national: \\ acupuncture, homéopathie, médecine manuelle, \\ Sainte-Ruffine, Maisonneuve, 1984. Les Médecines \\ différentes, un défi? (Rapport au ministre des Affaires \\ sociales et de la Solidarité nationale et au Secrétaire \\ d'État chargé de la santé), Groupe de réflexion \\ "Médecines différentes", Collection des rapports \\ officiels, Paris, La Documentation française, 1986.
}


clinical trials of homoeopathic remedies, and the ministry set up a Groupe de Recherches et d'Essais Cliniques en Homéopathie for this purpose. Dufoix hoped to create a centre at Cannes for assessing unconventional therapies, with a view to ultimately integrating nonstandard approaches into the medical curriculum. The tests were abandoned, however, after the first study showed no medical benefits, ${ }^{42}$ and Michèle Barzach, as minister of health, subsequently killed the still inchoate project. The initiative did lead to a 1986 report, with a preface by Dufoix, and indirectly to the survey of alternative medicines from the Ministry of Social Affairs mentioned above. ${ }^{43}$

The origins of this configuration of the French medical field can be traced back two centuries. Official medicine - and by the same token alternative medicine-was arguably constituted earlier in France than in other major European countries. This is, of course, a judgement that the as yet unwritten comparative history of this question may oblige us to revise, and it must be added that the boundaries of the official long remained the subject of vigorous dispute.

The beginnings of the process are visible under the Old Regime. The state played an important role through its sponsorship of institutions such as the Royal Society of Medicine, chartered in 1778, and charged with investigating epidemics and regulating the trade in secret remedies and mineral waters. The battle over mesmerism in the $1780 \mathrm{~s}$, which resulted in condemnations by the Royal Society, the Academy of Sciences, and the Paris Faculty of Medicine, marked a turning point, branding mesmerism as unorthodox, although it was the brainchild of a medical doctor who claimed scientific grounds for his novel approach. ${ }^{44}$ This was not, to be sure, the such first dispute over medical doctrines. Nor did any of the royal institutions that repudiated Mesmer enjoy such uncontested authority that it could issue its judgement as a matter of course; the battle was fought in the court of public opinion. ${ }^{45}$ The fault lines, moreover, did not run neatly between insider and outsider: Mesmer found some supporters among physicians. Still, the episode was striking for the degree of consensus on the character of mesmerism-by the end of the Old Regime its status as alternative medicine in the strong sense was clear-and for the rigour with which established institutions attempted to draw the boundaries. Offending doctorregents in Paris, for example, were struck off the faculty's registers.

In the nineteenth century, after the revolutionary hiatus of the 1790s, official medicine was reconstituted. Its authority may have owed something to the negative experience of the delegitimation of expertise during the Revolution. As George Weisz has shown, a new national medical elite emerged, whose chief locus of authority was the Royal Society's belated successor, the Royal Academy of Medicine, chartered in $1820{ }^{46}$ French medicine did not, however, return to the Old Regime; the old medical corporations were not restored, and licensed physicians enjoyed considerable freedom in choosing how to

\footnotetext{
${ }^{42}$ M J Mayaux, et al., 'Controlled clinical trial of homoeopathy in postoperative ileus', Lancet, 1988 (Mar 5), 1 (8584): 528-9.

${ }^{43}$ Les Médecines différentes, note 41 above; Barel and Butel, op. cit., note 4 above. The Dufoix project is described in Autrement, no. 85.

${ }^{44}$ Robert Darnton, Mesmerism and the end of the Enlightenment in France, Cambridge, Mass., Harvard University Press, 1968.
}

\author{
${ }^{45}$ See Laurence Brockliss and Colin Jones, The \\ medical world of early modern France, Oxford, \\ Clarendon Press, 1997, conclusion, parts A-B. \\ ${ }^{46}$ On the Academy, see George Weisz, The \\ medical mandarins: the French Academy of \\ Medicine in the nineteenth and early twentieth \\ centuries, New York and Oxford, Oxford University \\ Press, 1995.
}




\section{Matthew Ramsey}

practise medicine. Although the Academy hotly debated particular theories and therapies and occasionally achieved a consensus-on the worthlessness of homoeopathy, for example, in 1835-it often reached no firm conclusion, and colleagues were not excommunicated. In this sense, the Mesmer episode at the end of the Old Regime was not paradigmatic - indeed, a few nineteenth-century academicians spoke in favour of animal magnetism and phrenology. ${ }^{47}$ What was new was a uniform national professional monopoly. The medical practice legislation adopted under Bonaparte's Consulate in 1803 made France the recognized model for strict regulation of the medical field throughout the West and wherever Western medicine was emulated. ${ }^{48}$ In practice it proved difficult to distinguish sharply between insiders and outsiders, and even when the legislation was enforced, it hardly deterred the unqualified. In the larger culture, however, the experience of repression had tremendous symbolic import, reinforcing the deviant status of unreconstructed medical outsiders.

The principle of professional monopoly was never seriously at risk, but neither was it uncontested. A whig narrative would recount how it was reinforced under the Third Republic in the new medical practice legislation of November 1892, which gave medical syndicats (unions) the right to prosecute unauthorized practice, and reaffirmed, after the fall of the Vichy Regime, by an ordinance of September 1945, and then again in the new public health code promulgated under the Fifth Republic in October 1983. The reality is more complex: the import of the 1892 law was ambiguous, and its aftermath demonstrates less the hegemony of official medicine in the Pasteurian era than the dialectical relationship between official and alternative medicine, with rigour on one side engendering a countervailing militancy on the other. ${ }^{49}$

The 1892 law struck many contemporaries as more "liberal" than the legislation of 1803 , largely because it defined more narrowly the factors that constituted illegal medical practice, where the earlier enactment had been notoriously vague. Some courts, indeed, held that certain recidivists could be prosecuted for acts committed before the new legislation went into effect, but not for subsequent ones. Not only did the new law understandably make allowances for nursing care and for first aid in emergencies but it also required a pattern of unauthorized medical treatment to establish the offence. In addition, the appeal court of Angers notoriously accepted the argument put forward by the magnétiseurs that their activities did not come under the ban on unauthorized medical treatment, so long as they did not administer or prescribe remedies or perform surgical operations; according to this interpretation, mesmeric passes (passes magnétiques) did not

\footnotetext{
${ }^{47}$ See ibid., chs 3, 5 .

${ }^{48}$ Matthew Ramsey, 'The politics of professional monopoly in nineteenth-century medicine: the French model and its rivals', part III of Gerald L Geison (ed.), Professions and the French state, 1700-1900, Philadelphia, University of Pennsylvania Press, 1984, pp. 225-305.

${ }^{49}$ On the 1892 legislation, see René Roland, Les médecins et la loi du 30 novembre 1892: étude historique et juridique sur l'organisation de la profession medicale et sur ses conditions d'exercice, Paris, Bureau des lois nouvelles, 1893. On the
}

aftermath: Georges David, De l'exercice illégal de la médecine en France (law thesis, 1904), Fontenay-leComte, Charles Claireaux, 1904; V Gauthier,

Considérations sur l'exercice illégal de la médecine, Paris, Jules Rousset, 1900; and Émile-Auguste Berthomier, Charlatanisme et médecine illégale (Paris medical thesis), Paris, Librairie des Facultés de médecine, Ollier-Henry, 1910, ch. 5. On the political background: Jack D Ellis, The physicianlegislators of France: medicine and politics in the Third Republic, 1870-1914, Cambridge University Press, 1990. 


\section{Alternative Medicine in Modern France}

in themselves constitute medical treatment. ${ }^{50}$ The issue was not finally resolved by France's highest appeal court, the Cour de Cassation, until the very end of the decade, when it found in favour of the rigorists. ${ }^{51}$ Thereafter, although the courts continued to show leniency toward healers who claimed that a supernatural agency empowered them to cure through the laying on of hands, very similar gestures by magnétiseurs, who claimed to manipulate an invisible fluid, were deemed punishable. The most celebrated healers of the early twentieth century used medical magnetism, and all wound up in trouble with the law. ${ }^{52}$ Even then, certain grey areas remained. Diagnosis was not explicitly defined as illegal practice until the Health Code of 1945. The elaborate definition of medical practice in the Health Code of 1983, worded so as to include any procedure used to treat any disease, real or imagined, is an oblique comment on the uncertainties of French jurisprudence in the intervening years. ${ }^{53}$

A similar observation would apply to the state's tight control of medical education and training, which may seem absolute when regarded from certain perspectives but was never complete or uncontested. A law adopted in 1875, when the legislature of the young Third Republic was still dominated by conservatives sympathetic to the Catholic Church, granted freedom of higher education, and a Catholic medical faculty was duly established at Lille. In 1880 the victorious republicans stripped private institutions of the right to the title of university - they could be known only as facultés or écoles libres-and reclaimed for the state a monopoly over the final qualifying examinations and the awarding of degrees. ${ }^{54}$ In practice it undoubtedly remained harder than in the US or the UK to organize independent schools or professional societies. The strong Heilpraktiker organizations that emerged in Germany would be difficult to imagine in the French context, and even today

\footnotetext{
${ }^{50}$ On the Angers decision and the reactions of the medical profession, see the Bulletin officiel de l'Union des Syndicats médicaux de France (hereafter BOUSMF), 1894, 8: 161, 177; for some of the subsequent cases and debates, see ibid., 1895, 9: 254-6. For an overview, see Gauthier, op. cit., note 49 above, pp. 46-8, and David, op. cit., note 49 above, pp. 183-4 (on masseurs and magnétiseurs) and 190-2 (on somnambules). The chief parliamentary sponsor of the medical practice bill, Chevandier, was said to have indicated during the debates that magnétiseurs and masseurs would be exempted, even though the legislators had not written an explicit exception into the final text. The physicians' syndicats vigorously disputed this interpretation. See, for example, Union des syndicats médicaux de France, Application et interprétation de la loi du 30 novembre 1892 sur l'exercice de la médecine, Paris, 1895,4 pp., pamphlet in Archives Nationales [hereafter AN] BB ${ }^{18}$ 6582. The archival record makes clear that Chevandier and his committee did not intend to exempt massage and magnetism as medical treatments; only scientific experimentation would be open to lay persons. See AN C 5492, Chambre des députés, registre de la Commission chargée de l'examen de la proposition de loi de M Lockeroy [et] $2^{\circ}$ de M Chevandier et
}

plusieurs de ses collègues, relatives à l'exercice de la médecine.

${ }^{51}$ BOUSMF, cited in note 50 above, 1901, 15: 3.

52 Henri Beaudot, L'Exercice illégal de la médecine et le charlatanisme: ressemblances et différences dans leurs éléments et dans leur répression (Lyons law thesis), Lyons, Imprimerie Lyonnaise, 1938, pp. 71-2, 88.

53 The current code, as modified in 1996, defines as an illegal practitioner "toute personne qui prend part habituellement ou par direction suivie, même en présence d'un médecin, à l'établissement d'un diagnostic ou au traitement de maladies ou d'affections chirurgicales, congénitales ou acquises, réelles ou supposées, par actes personnels, consultations verbales ou écrites ou par tous autres procédés quels qu'ils soient, ou pratique l'un des actes professionnels prévus dans une nomenclature fixée par arrêté du ministre de la santé publique pris après avis de l'Académie nationale de médecine sans être titulaire d'un diplôme, certificat ou autre titre ... . exigé pour l'exercice de la profession de médecin ..." (article L.372).

54 See George Weisz, The emergence of modern universities in France, 1863-1914, Princeton University Press, 1983, chs 3-4. 


\section{Matthew Ramsey}

the prospects for autonomous professionalization and self-regulation are less bright than in the UK. ${ }^{55}$ Legal and institutional constraints help explain why there have been no indigenous French counterparts to occupations such as osteopathy and chiropractic, which are in effect rival medical professions, and why France proved less receptive than Germany and the US to the development of organized counterhegemonic medical movements. The two most prominent movements, homoeopathy and the various avatars of mesmerism, were originally foreign imports.

We should not, however, exaggerate the weakness of French voluntary organizations and the dominance of the centralized state. This is one of those cases in which it matters both that the glass is half empty and that it is half full. Despite the weight of government regulation, France has a long tradition of independent medical schools, associations, and periodicals, such as those headed by Henri Durville, the leader of organized medical magnetism at the beginning of the twentieth century. Maurice Mességué, healer, bestselling author, and political leader of la médecine libre in the mid-twentieth century, established a Groupement National des Praticiens de la Médecine Libre, whose stated goals were to maintain standards among the "free practitioners" and regularize relations with official medicine. ${ }^{56}$ Osteopaths and chiropractors now have their own national organizations and maintain voluntary registers of practitioners; Paris is the site of the Centre Européen d'Enseignement Supérieur de l'Ostéopathie.

The strength of the state's sponsorship of official medicine and the weakness of its links to nonstandard practices have had a paradoxical effect on the development of alternative medicine. At one level they have reinforced what might be called the countercultural legitimacy of medical outsiders, making it possible for healers taken to court to emerge as popular heroes. Alternative medicine has a long martyrology. Its most celebrated leaders have been tried for illegal medical practice, from the radical chemist François-Vincent Raspail and the magnétiseur L-P Mongruel in the mid-nineteenth century to Durville and Mességué; indeed, they owed a good deal of their notoriety to the publicity surrounding their trials. In some cases alternative medical practice merged with other forms of deviance and defiance of state authority, as when healers helped conscripts simulate disqualifying medical conditions to escape military service during the Napoleonic wars. ${ }^{57}$ Resistance to the privileges of official medicine similarly reinforced the association of alternative medicine with political radicalism. Robert Darnton's much controverted argument that rejection at the hands of the academic establishment embittered figures such as Jean-Paul Marat and helped turn them to the path of insurrection may not go far towards explaining the general origins of the French Revolution, but it does illuminate the radically egalitarian streak in certain forms of French alternative medicine. ${ }^{58}$

On the other hand, official proscription reinforced the yearning of many medical outsiders for legitimacy. They often won the protection of France's social and political elites, and they actively sought the approval of its medical establishment. Probably only a minority revelled in their outsider status. More typical is a proposal put forward in 1949

\footnotetext{
${ }^{55}$ See S L Cant and U Sharma,

'Professionalization of complementary medicine in the United Kingdom', Complementary Therapies, 196, 4: 157-62.

${ }^{56}$ See Laplantine and Rabeyron, op. cit., note 17 above, p. 63.
}

\footnotetext{
${ }^{57}$ Matthew Ramsey, 'Conscription, malingerers, and popular medicine in Napoleonic France', Proceedings of the Consortium on Revolutionary Europe, 1978, Athens, Georgia, 1980, pp. 188-99.

${ }^{58} \mathrm{See}$, for example, Darnton, op. cit., note 44 above.
} 


\section{Alternative Medicine in Modern France}

for a separate statute for la médecine libre that would have recognized its independent validity but encouraged contacts and cooperation with the world of official medicine. ${ }^{59}$

For the historian of French alternative medicine, the challenge is to find ways to map this highly varied terrain with fewer of the sorts of prominent topographical features-the major leaders, schools, and movements-that mark the German, British, and American landscapes, and with an archival record that largely belongs to the state and tends to emphasize control and repression. ${ }^{60}$ This essay will not attempt to describe the full range of activities in which medical outsiders engaged, ${ }^{61}$ or of nonstandard medical practices and beliefs-some of which, it should be emphasized, had adherents in the world of official medicine or took generally accepted principles and carried them to an extreme. The majority of medical outsiders, particularly in rural areas, could not be said to have embraced a coherent alternative medical system-the nuns, for example, who were arguably the most numerous providers of health care in the provinces in the nineteenth century, ${ }^{62}$ or the bonesetters who dealt with fractures, sprains, and dislocations and might - some of them - have muttered a prayer or charm as they worked. Some of the ubiquitous vendors of secret remedies boasted of medical knowledge far superior to anything taught in the faculties, but many simply claimed to know how to compose medicines whose wondrous powers to cure had been demonstrated by experience; their claims were counterhegemonic only in the sense that they regularly took credit for having saved patients "abandoned" by the physicians. ${ }^{63}$

Rather than attempt to establish a systematic catalogue or taxonomy of these divergent practices, the next two sections, which trace the development of French alternative medicine through the nineteenth and twentieth centuries, will emphasize a few key forms of medicine that were alternative in the strong sense-far from the only or even the most prevalent forms of outsider or nonstandard medicine, but arguably those that contributed the most to shaping their public image.

\section{Alternative Medicine, Spiritualism, and Radical Politics in the Nineteenth Century}

Alternative medicine in nineteenth-century France was less strongly characterized by coherent "sects" than its American, English, and German counterparts. The reasons may be as much cultural as institutional and legal; there is not just a parallel but often a direct

\footnotetext{
${ }^{59}$ Dr Charles Claoué, of the Centre d'études biologiques et médicales, Malaise social dans la médecine: pour un statut de la médecine libre; proposition de loi, Paris, L'Activité scientifique et médicale, 1949.

${ }^{60}$ One interesting exception: the records of the homoeopathic physician Léon Vannier, which were acquired by the Boiron firm and studied by Olivier Faure; see Faure, 'La Clientèle d'un homéopathe parisien au $\mathrm{XX}^{\mathrm{e}}$ siècle: recherches sur les patients de L Vannier, 1928-1948', in Faure, Praticiens, note 30 above, pp. 175-96. Vannier, apart from being a medical doctor, was an exceptional figure, the most prominent French homoeopath of the interwar period.

${ }^{61}$ An overview for the early nineteenth century
}

can be found in Matthew Ramsey, Professional and popular medicine in France, 1770-1830: the social world of medical practice, Cambridge University Press, 1988.

${ }^{62}$ See Jacques Léonard, 'Les Médecins et les soignants: femmes, religion et médecine: les religieuses qui soignent, en France au XIX ${ }^{\mathrm{e}}$ siècle', Annales: économies, sociétés, civilisations, 1977, 32: 858-62.

${ }^{63}$ See Matthew Ramsey, 'Academic medicine and medical industrialism: the regulation of secret remedies in nineteenth-century France', in Ann La Berge and Mordechai Feingold (eds), French medical culture in the nineteenth century, Amsterdam and Atlanta, Rodopi, 1994, pp. 25-78. 


\section{Matthew Ramsey}

connection between the flourishing of religious sects and alternative medical movements in Protestant Europe and North America, and the relative dearth of sects and organized movements of alternative medicine in Catholic Europe. Only two well-defined movements stand out in France-medical magnetism and homoeopathy. Two other distinctive approaches with many counterparts elsewhere were the radical neohumoralist systems favoured by promoters of purgative panaceas, such as the surgeon Louis Leroy and his English counterpart James Morison, and the various forms of "natural medicine" and phytotherapy, linked to homoeopathy by a common hostility to the poisons of the allopaths. French exponents of the latter approach in the mid-nineteenth century included Ferdinand Caunière, known as the "Indian physician", a self-professed enemy of medicine as taught in the European medical faculties; for Caunière, Western medicine, unlike surgery, had made virtually no significant advances. He called his system, which substituted vegetable for mineral remedies, Indo-Malagasy Natural Medicine, after the countries where he claimed to have studied it, but he saw its basic elements as very widespread among the less civilized peoples of the world (les peuples encore peu policés). ${ }^{64}$

The discussion that follows will concentrate on one relatively coherent form of alternative medicine, medical magnetism. It will have little to say about homoeopathy in France, where Samuel Hahnemann spent the successful last phase of his career, and where his French widow, Mélanie d'Hervilly, carried on his legacy. In the French context, homoeopathy did not develop either well-organized lay movements, as in Germany, or the sorts of parallel professional institutions seen in the US and to a lesser extent in Germany. In the last four decades of the century, the number of adherents actually declined. ${ }^{65}$ Nor will it be possible to give much attention to the preachers of gloriously idiosyncratic doctrines who marched across the medical stage, particularly in the middle decades of the century. Each is in a sense unique, though in the end many of them begin to sound alike, having read the same literature, absorbed the same influences, and nursed the same grievances. One will have to stand in for many: Jan Hendrick Vries, known as le Docteur noir, who never tired of repeating that he had been trained in Western medicine but found it wanting. His eclectic medical system incorporated elements of homoeopathy, mesmerism, and exotic phytotherapy, ${ }^{66}$ but it seemed overshadowed at times by his deeper preoccupations with utopian prophecy, ecumenical religion, international brotherhood, and scientific progress. ${ }^{67}$

\footnotetext{
${ }^{64}$ Caunière, La Médecine naturelle devant ses juges et devant l'opinion, Paris, E Dentu, 1858; cf. a pamphlet by one of his apologists, $\mathrm{L}$ Vanard, $L a$ Médecine naturelle: requête à MM. les juges de police correctionnelle en faveur d'un médecin étranger qu'on traduit en justice, Paris, E Dentu, 1858.

${ }^{65}$ Robert Jütte, 'The professionalization of homoeopathy in the nineteenth century', in idem and John Woodward (eds), Coping with sickness: historical aspects of health care in a European perspective, Sheffield, European Association for the History of Medicine and Health Publications, 1995, pp. 45-66.

${ }^{66}$ Rénovation de la science médicale par le docteur Vries, traduit du hollandais (prospectus), Paris, Imprimerie G-A Pinard, 1859.
}

${ }^{67}$ Vries, Question du soleil, nouveau signe des temps, Paris, Imprimerie de P Dupont, 1868; Ordre de Dieu d'ériger le temple du royaume du Christ prophétisé par Salomon . . Réforme universelle de la civilisation et l'union des nations. Érection à Paris d'un temple symbolique en albâtre réunissant et confondant en un culte unique le protestantisme, le catholicisme et le judaïsme, auxquels viennent se joindre toutes les religions professées dans l'univers; Paris, centre du monde, devient le soleil dont les rayons répandent partout l'amour, l'union et la civilisation des peuples, Paris, Imprimerie de Dubuisson, 1856; Remplacement de la vapeur; nouvelle force motrice appliquée à tous les usages de la navigation et de l'industrie . . . Paris, Imprimerie de Renou et Maulde, 1870. 
A central strand of alternative medicine in France and elsewhere had its roots in the Counter-Enlightenment of the late eighteenth century. In a classic study, Auguste Viatte showed the pervasiveness of illuminism and theosophy in European intellectual life during this period and the affinities between early romanticism and the spiritualism of a Swedenborg or Jung-Stilling. ${ }^{68}$ The field of medicine richly illustrates these same developments, from the occult extravagances of Cagliostro at the end of the Old Regime to Hahnemann's more discreetly vitalist Organon, published in 1810 . The most prominent example, however, is mesmerism. It began, in Mesmer's own writings, as a theory concerning a magnetic fluid theoretically compatible with materialism. In other hands, however, it soon developed into a spiritualist movement, which spread throughout Europe by the end of the Old Regime. In Lyons, for example, the mesmerist Société La Concorde had close links to Swedenborgianism; Louis-Claude de Saint-Martin, dispensing with Mesmer's material fluid, sought integration into the spiritual realm. The technique for inducing "mesmeric somnambulism" (hypnotic trances) developed by the Chastenet de Puységur brothers subsequently provided the basis for the widespread popular medical practice in which a magnétiseur induced a trance in a somnambule, who used her special visionary powers to diagnose disease and prescribe remedies. ${ }^{69}$ Magnétiseurs, however, also claimed to heal in the mesmerist manner through their manipulation of the magnetic fluid, a phenomenon they considered as much a part of the natural physical world as gravitational attraction. The coexistence of such claims gave medical magnetism an ambiguous status in the eyes of the public and the medical profession. The somnambules could purportedly attain a realm inaccessible to ordinary human understanding, either through their own extraordinary mental powers or the assistance of preternatural agencies, but at least their trances could be witnessed. Mesmeric healing was said to exploit a natural force for therapeutic ends, but one that by its very nature could not be observed.

Within the magnetic movement itself, one can see a growing commitment first to spiritualism, in the common acceptation of the first half of the nineteenth century-that is, a belief in mind/spirit/soul as an independent and irreducible reality-and then to a belief in the possibility of interacting with ghosts and preternatural and supernatural agencies. At mid-century, Mongruel wrote of "the eternal truth of the subordination of the physical to the moral, in other words Magnetism". ${ }^{70}$ Although he rejected what he characterized as material "superstitions", such as the ancient practice of haruspicy from the entrails of a sacrificial victim, he happily endorsed divination and prophecy through dreams and identified with the biblical prophets and apostles. Half a century later, the Journal du magnétisme reaffirmed magnetism's essential ontological dualism: "Since man is both spirit and matter, soul and body, Energy-Life and a machine designed for movement, Medicine must deal with the spirit, soul, Energy-Life, and the motive force as well as the body, matter, and the organism that is to be put into regulated motion."71

\footnotetext{
68 Viatte, Les Sources occultes du romantisme: illuminisme, théosophie, 2nd ed., 2 vols, Paris, Librairie Honoré Champion, 1979; 1st ed., 1927.

${ }^{69}$ See Edelman, op. cit., note 13 above, and Tony James, Dreams, creativity and madness in nineteenth-century France, Oxford, Clarendon Press, 1995, ch. 3, 'Somnambulism, natural and magnetic'.

${ }^{70}$ Mongruel, Appel de la Sociéte l'Union-
}

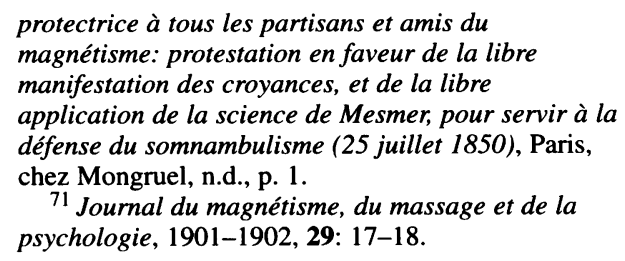

protectrice à tous les partisans et amis du magnétisme: protestation en faveur de la libre manifestation des croyances, et de la libre application de la science de Mesmer, pour servir à la défense du somnambulisme (25 juillet 1850), Paris, chez Mongruel, n.d., p. 1.

71 Journal du magnétisme, du massage et de la psychologie, 1901-1902, 29: 17-18. 


\section{Matthew Ramsey}

In many of its manifestations, mature medical magnetism could fairly be called a religious movement. Mongruel's contemporary Henri Delaage, the grandson of the medical graduate and chemist Jean-Antoine Chaptal, who served as Napoleon's minister of the interior, was a committed Christian who hoped to use the occult in the struggle with atheist materialism. ${ }^{72}$ The most celebrated magnétiseur at the end of the century, HenriAuguste Jacob, commonly known as le zouave Jacob (he had joined the army during the Crimean War and wound up as a trombone player in a regiment of Zouaves), developed an eclectic system permeated by religious belief. ${ }^{73}$ As he told his story, when he returned to his native village he discovered that he had the power to heal by his touch; he attributed this virtue to a fluid he had received from an 8,000-year-old Indian wise man named Krishna. His fully developed medical system began with hygiene and basic humoralist theory but quickly moved to the healing force of the vital fluid. Certain human beings serve as conduits for spirits entrusted by God with the task of transmitting the healing fluid to patients; hence healers need to study spirit science. Jacob criticized materialist therapeutics-including phytotherapy, since even harmless plants could be dangerous when abused, and homoeopathy, since in his view the homoeopaths used the same poisons as the allopaths, only in smaller doses. ${ }^{74}$ Jacob made a great show of his contempt for the idiocy of medical insiders; the profession and mainstream press mocked his "theological" therapeutics. $^{75}$

By the end of the century, medical magnetism was closely associated both with Christian revivalism and with spiritualism in the sense of commerce with spirits"spiritism", to use the term given currency by Allan Kardec, to whom invisible intelligences had revealed a spirit world that predated and would outlive everything else. ${ }^{76}$ Magnetic healers regularly invoked Kardec's name. Conversely, most mediums were drawn to healing, attributing the good works performed by magnétiseurs to the agency of good spirits. ${ }^{77}$ Magnetism, indeed, should be seen in the context of a much more widespread pattern of interest in the occult, prophecy, mysticism, messianism, and the miraculous, often linked to medicine. The fin de siècle saw an extraordinary efflorescence of medico-religious movements that were sects in the strict sense of the term. ${ }^{78}$

Medical magnetism and the larger spiritist movement with which it merged might seem like obvious fringe phenomena, but their relationship with official medicine remained more complex than the reciprocal animadversions of the magnétiseurs and their detractors

\footnotetext{
${ }^{72} \mathrm{H}$ Delaage, Le Monde occulte, ou mystères $d u$ magnétisme dévoilés par le somnambulisme; précédé d'une introduction sur le magnétisme, par le père Lacordaire, Paris, Paul Lesigne, 1851.

${ }^{73}$ For a brief account of Jacob's career, see Pierre Darmon, La Vie quotidienne du médecin parisien en 1900, Paris, Hachette, 1986, pp. 170-2.

74 [Henry Jacob], L'Hygiène naturelle par le zouave Jacob, ou l'art de conserver la santé et de se guérir soi-même, Paris, chez l'auteur, n.d. [1868].

75 [Jacob], Police correctionnelle; procès $d u$ zouave Jacob; charlatanisme, ignorance, impuissance et agonie des corporations médicales, n.p., Revue théurgique, [1891].

${ }^{76}$ Allan Kardec [Hippolyte-Léon-Denizard Rivail), The spirits' book. ..., trans. Anna
}

Blackwell, Boston, Colby and Rich, Publishers, 1875; reprint, New York, Arno Press, 1976. For an overview of French spiritism, see Aubrée and Laplantine, op. cit., note 23 above, part 1 , 'Genèse, formation et évolution d'un mouvement social: le spiritisme en France dans la seconde moitié du XIX ${ }^{\mathbf{e}}$ siècle jusqu'à la Première Guerre Mondiale'. On the place of the occult in the cultural life of France at the end of the nineteenth century, see Eugen Weber, France, fin de siècle, Cambridge, Mass., Harvard University Press, 1986, pp. 32-5.

${ }^{77}$ Edelman, op. cit., note 13 above, p. 95.

${ }^{78}$ See Germain Galérant, Médecine de campagne: de la Révolution à la Belle Époque, Paris, Plon, 1988, p. 70, and Darmon, op. cit., note 73 above, pp. $166-8$. 
might suggest. ${ }^{79}$ The phenomenon of the magnetic trance was studied by committees of the Academy of Medicine under the Restoration and July Monarchy, but with inconsistent results; an 1831 report suggested that the phenomenon was real, though there was a clear risk of fraud, whereas an 1837 report found that it was not adequately proved. The way in which medicine eventually co-opted hypnotism and a version of the idea of mental states not accessible to ordinary consciousness forms a celebrated chapter in the history of psychiatry. ${ }^{80}$ At the same time, however, physicians became, if anything, more sceptical of the magnétiseurs and somnambules themselves, deriding the idea of the magnetic fluid and suggesting that the somnambules simulated the visions used for divination and medical diagnosis. Charcot, who considered the hypnotic trance a symptom of hysteria, attacked the popular magnétiseurs, as did his disciple Gilles de la Tourette, who underscored the medical and moral dangers of hypnotism. ${ }^{81}$

There were exceptions, however. The Spanish-born physician Gérard Encausse (18651916), for example, known as Papus, director of the hypnotherapy laboratory at the Hôpital de la Charité in Paris, was an enthusiast for the occult, a sometime theosophist and active Martinist who advised Tsar Nicholas II on matters both medical and paranormal. For Papus, "magnetism is the spiritism of the living, spiritism is the magnetism of the dead". 82 Professional scientists and philosophers far more prominent than Encausse took an interest in the paranormal and the spiritual, either as phenomena to which science needed to turn its attention, or as a realm of experience that lay beyond the possibility of scientific explanation. The Nobel prize-winning medical scientist Charles Richet of the Sorbonne believed in spirits. The philosopher Henri Bergson, future Nobel laureate in literature, delivered the presidential address in 1911 to the English Society for Psychical Research, in which he adduced the appearance of ghosts as evidence of the immortality of the soul. ${ }^{83}$

Medical magnetism had a similarly complex relationship with Catholicism. Its links to the religious revival of the late nineteenth century, with its emphasis on faith and the presence of the supernatural in the world, might suggest a natural ally for a Church confronting a strong materialist contingent within the medical profession and a French Republic increasingly committed to positivism and anticlericalism. In a sense spiritualist healing and pilgrimages to Lourdes, which by 1908 reached an annual total of 1.5 million, were cognate phenomena. Not all religious practices, however, were accepted as orthodox,

\footnotetext{
${ }^{79}$ See Ruth Harris, Murders and madness: medicine, law, and society in the fin de siècle, Oxford University Press, 1989, subchapter on 'Spiritualism, magnetism, and medical authority', pp. 192-207, and Edelman, op. cit., note 13 above, pp. 54-9, 180-6, and passim.

${ }^{80}$ See Henri F Ellenberger, The discovery of the unconscious: the history and evolution of dynamic psychiatry, New York, Basic Books, 1970. For a nuanced account of the relationship between latenineteenth-century psychiatry and the mesmerist tradition, see Anne Harrington, 'Hysteria, hypnosis, and the lure of the invisible: the rise of neomesmerism in fin-de-siècle French psychiatry', in W F Bynum, Roy Porter, and Michael Shepherd (eds), The anatomy of madness: essays in the history
}

of psychiatry, vol. 3, London and New York, Routledge, 1988, pp. 226-46.

${ }^{81}$ Georges-Albert-Édouard-Brutus Gilles de la Tourette, L'Hypnotisme et les états analogues au point de vue médico-legal: les états hypnotiques et les états analogues, les suggestions criminelles, cabinets de somnambules et sociétés de magnétisme et de spiritisme, l'hypnotisme devant la loi, 2nd ed., Paris, E Plon, Nourrit et $\mathrm{C}^{\mathrm{ie}}, 1889$.

${ }^{82}$ Congrès spirite et spiritualiste international de 1889 [Paris 9-16 September 1889], Paris, Librairie spirite, 1890, quoted in Edelman, op. cit., note 13 above, p. 95.

${ }^{83}$ Cited in Thomas A Kselman, Death and the afterlife in modern France, Princeton University Press, 1993, p. 143. 


\section{Matthew Ramsey}

and the relationship between the Church and miraculous healing was far from simple. The hierarchy had long condemned appeals to saints not on the Church calendar, the healing powers attributed to certain shrines, and other practices and beliefs it deemed superstitious. This pattern, it is true, altered somewhat in the last decades of the nineteenth century. The institutional Church, in part because of its conflict with the secularizing Republic but also, more broadly, in response to the challenges of scientism, sanctioned and tried to co-opt the rebirth of the miraculous. ${ }^{84}$ Animal magnetism, however, remained suspect, and the Church continued to condemn it, together with hypnotism, mediums, and the various forms of spiritism. 85

This on-going challenge to medical magnetism should remind us of the persistent and pervasive presence of the Church as an official institution-no longer, in nineteenthcentury France, the established church of the Old Regime, except under the Bourbon Restoration, but recognized in Napoleon's Concordat as the "religion of the great majority of Frenchmen" and still linked to the state in certain ways, even after the official separation of 1905 . These complexities point to a crucial limitation of any simple dichotomy between official and alternative: the official was itself a contested category, as is nowhere more clearly exemplified than in the overlapping struggles between Church and State, Catholicism and scientism, during the first decades of the Third Republic. A century later Laplantine could still write that "two forms of legitimation are possible in our culture: scientific or religious." 86 Medical magnetism might be described as doubly alternative, vis-à-vis both the Church and official medicine. Yet other practices, even if condemned by official medicine, might be well within the realm of religious orthodoxy and far from marginal within the community of believers. In a given society, some nonstandard forms of medicine-as defined against modern biomedicine-may not seem strongly alternative because scientism itself may be far from hegemonic in the larger culture.

At the same time, we should not represent the relationship between the Church and practising Catholics, on the one hand, and official medicine and the medical profession, on the other, as one of simple antagonism. To be sure, physicians eagerly joined anticlerical campaigns from the days of the radical Enlightenment to the emergence of the Radical Party under the Third Republic; the Church under Pius IX anathematized positivism and materialism, among other cardinal sins of modernity. But many other physicians considered themselves good Catholics and questioned the premises of radical materialism and scientism. ${ }^{87}$ The vitalism and spiritualism associated with the medical tradition of the Montpellier faculty provided a convenient meeting ground. Pasteur was a staunch Catholic and anti-materialist, whose work invalidating spontaneous generation seemed to support vitalism and even philosophical spiritualism. ${ }^{88}$ The future Nobel

\footnotetext{
${ }^{84}$ Idem, Miracles and prophecies in nineteenthcentury France, New Brunswick, NJ, Rutgers University Press, 1983.

${ }^{85}$ Edelman, op. cit., note 13 above, pp. 167-71; Pierre Guillaume, Médecins, Église et foi, $X I X^{e}-X X^{e}$ siècles, n.p., Aubier, 1990, pp. 52-4.

${ }^{86}$ Laplantine and Rabeyron, op. cit., note 17 above, p. 10.

${ }^{87}$ Léonard suggests that the medical profession in
}

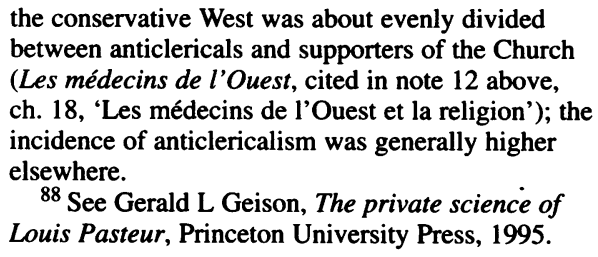

the conservative West was about evenly divided between anticlericals and supporters of the Church (Les médecins de l'Ouest, cited in note 12 above, ch. 18, 'Les médecins de l'Ouest et la religion'); the incidence of anticlericalism was generally higher elsewhere.

${ }^{88}$ See Gerald L Geison, The private science of Louis Pasteur, Princeton University Press, 1995. 


\section{Alternative Medicine in Modern France}

laureate Alexis Carrel visited Lourdes in 1903; without ever renouncing science or the scientific method, he was convinced of the reality of phenomena that science could not as yet explain and became a firm believer in the curative powers of prayer. Other physicians participated with sincere enthusiasm in the work of the medical bureau at Lourdes, which attempted to certify miraculous cures by eliminating possible naturalistic explanations. ${ }^{89}$

Medical magnetism, however, was doubly excluded and faced not only ecclesiastical proscription but also state prosecution for swindling and illegal medical practice. By the mid-nineteenth century its counterhegemonic status was well established, and in the hands of its leading adepts it assumed the combative and politicized form that Mongruel called "militant magnetism". Like Mesmer's followers at the end of the Old Regime, they mounted a pamphlet campaign to win the support of public opinion. Mongruel declared himself a martyr and tried to rally the troops for a great meeting in Paris in 1850 to form a defensive alliance (Union protectrice) to organize resistance. ${ }^{90}$

The political activism of the magnétiseurs reached a climax at the beginning of the twentieth century, under the leadership of Durville, after the Cour de Cassation had made clear that they could be prosecuted under the medical practice legislation of 1892. Thanks in part to the law of 1875 on freedom of education and to an 1884 measure that legalized trade unions, they had established training centres, notably the École Pratique de Magnétisme et de Massage, headed by Durville, and professional organizations and lobbies such as the Syndicat des Masseurs et Magnétiseurs and the Société Magnétique de France. They now formed a Comité d'Initiative Magnétique and a Ligue Nationale pour la Pratique du Massage et du Magnétisme par les Masseurs et les Magnétiseurs and organized a huge petition campaign to persuade the legislature to amend the law of 1892 to re-legalize their activities. ${ }^{91}$ Although the effort ultimately failed, the magnétiseurs and their masseur allies collected thousands of signatures from people in all walks of life, from modest artisans and shopkeepers to the socially and politically prominent. ${ }^{92}$ Signers included the leading lights of spiritism, but also some physicians. Durville went out of his way to win allies within the medical profession and published all the writings he could find by physicians that supported or seemed to support the position of the magnétiseurs. ${ }^{93}$

Not all the medical men who lent their name to the drive to amend the law of 1892 were endorsing magnetism, medical massage, or spiritism; some based their commitment on political principles, on the libertarian values proclaimed by the magnétiseurs. Alternative medicine in the strong sense was associated with what might be called alternative politics, a connection dating back, like medical magnetism, to the late eighteenth century and mesmerism. Darnton has given a celebrated description of the links between mesmerism

${ }^{89}$ See Carrel, The voyage to Lourdes, trans. Virgilia Peterson, New York, Harper \& Brothers, 1950. The important synoptic study by Ruth Harris, Lourdes: body and spirit in a secular age, London, Allen Lane/Penguin, 1999, appeared too late to be consulted for this essay.

${ }^{90}$ L-P Mongruel, op. cit., note 2 above.

${ }^{91}$ For the background, see the Journal du magnétisme, du massage et de la psychologie, 1901-1902, 56th year, vol. 29, no. 1 (January 1901). Durville develops the magnetizers' position in Le
Massage et le magnétisme sous l'empire de la loi du 30 novembre 1892; . . . , Paris, Librairie du magnétisme, 1894. For the perspective of the organized medical profession, see BOUSMF, cited in note 50 above, 5 January 1902.

92 AN C 5998-6000 and C 7778.

${ }^{93} \mathrm{H}$ Durville (ed.), Arguments des médecins en faveur de la pratique du massage et du magnétisme par les masseurs et les magnétiseurs; . . , 3 parts, Paris, Librairie du magnétisme, n.d. 
and radical politics in the careers of J-P Brissot, Nicolas Bergasse, and J-L Carra, among others. Mesmer's universal harmony of the physical universe would have its parallel in a Rousseauean social and political harmony. ${ }^{94}$

Similar associations of alternative medicine with radical politics can be found throughout the nineteenth century, often featuring variants of the utopian and Christian socialist doctrines popular around the time of the Revolution of 1848-in the Mongruel circle, for example. The adherents are comparable to, though perhaps less prominent than, the exponents of political radicalism and spiritualist alternative medicine in Britain, as described in the work of J F C Harrison on radicalism and the medical fringe, or of Logie Barrow on the Swedenborgian general practitioner J J Garth Wilkinson. ${ }^{95}$ A more conspicuous pattern in France was the link between radical democracy, and sometimes socialism, and a medical system that was demotic in the sense that it was cheap, easily learned, and in principle accessible to the people. The most celebrated example was Raspail, who did battle with the doctors not only out of political conviction but also to promote his own medical system, and who used his prosecution for illegal medical practice as the occasion to publicize both his medical and his political views. ${ }^{96}$ Unlike some other radicals, who in effect sought to popularize a version of official medicine, Raspail was an exponent of a genuinely nonstandard medical system, with a pathology based on irritating microscopic parasites, and a therapeutics based on camphor. Raspail's dogmatism was a source of irritation to an even more militant critic of official medicine, the anarchist physician Ernest Cœurderoy, who in 1849 was sentenced in absentia to deportation for his political activities; for Cœurderoy, Raspail was the worst enemy of the medical establishment, and yet he hoped to substitute his own system for existing ones. ${ }^{97}$ Raspail's pronouncements, it is true, were sometimes contradictory; in the same breath he could denounce the ignorant doctors and their antique privileges and call for the establishment of a reformed medical corps as a magistracy with life tenure, salaried by the state. On the whole, though, he argued for free competition, sustained by universal suffrage in the political realm. With both Raspail and Cœurderoy, like some of their counterparts in Victorian England, one has the sense that hatred of elite privilege and professional monopoly weighed far more heavily than questions of medical doctrine.

After 1870, the old anti-establishment rhetoric resurfaced on the socialist Left and the radical fringe, represented, for example, by a veteran of the rhetorical wars of the Second Empire, the pharmacist Jean-Pierre Hureaux, Christian republican, medical popularizer, and self-announced founder of an Institute of Human Emancipation. ${ }^{98}$ Militant medical republicanism may paradoxically have been weakened, though, by the success of the conservative Third Republic, which achieved legitimacy in large part by dissociating itself

\footnotetext{
${ }^{94}$ Darnton, op. cit., note 44 above.

${ }^{95}$ Harrison, 'Early Victorian radicals and the medical fringe', in Bynum and Porter (eds), op. cit., note 11 above, pp. 198-215; Barrow, 'An imponderable liberator: J J Garth Wilkinson', in Cooter (ed.), op. cit., note 8 above, pp. 89-117.

${ }^{96}$ François-Vincent Raspail, Histoire naturelle de la santé et de la maladie . . . , in Daniel Ligou (ed.), François-Vincent Raspail, ou le bon usage de la prison . . . , Paris, J Martineau, 1968, pp. 511-13.
}

\footnotetext{
${ }^{97}$ Cœurderoy, Jours d'exil, London, 1855; reprint, 3 vols, Paris, P-V Stock, 1910-11, vol. 1, pp. 388-90, 435.

${ }^{98}$ Hureaux, Le Code moral de la République ou de l'esprit chrétien passé majeur, n.p., n.d.; La Régénération médicale pour tous: notice sur l'art de se guérir soi-même avec certitude enseigné par la nature, Paris, les principaux librairies, 1861; Le Salut social de la nation: la France ouvrière libre et la victoire sociale, Paris, Librairie générale, 1888.
} 
from the heritage of the radical French Republic of 1792-94, and which formed a powerfully symbiotic relationship with the medical and scientific establishments. ${ }^{99}$ More generally, the long-standing link between alternative medicine and radical democracy seems to have lost something of its raison d'être with the spread of universal suffrage in Europe, together with the beginnings of social insurance plans that in effect democratized access to the services of official medicine. But it survived, as the political campaigns of the magnétiseurs at the end of the century clearly showed. Mouroux, one of the defendants in the court cases testing the new law of 1892 , invoked liberty, equality and fraternity, the rights of man, and the other great principles of 1789 that the Third Republic claimed to uphold. Magnetism was among other things a form of individual property, which the Declaration of the Rights of Man had proclaimed a sacred right. ${ }^{100}$

\section{The Twentieth Century: Holism, Naturopathy, Religion and Conservative Politics}

In France as elsewhere, the extraordinary development of biomedicine in the twentieth century did not, as some physicians anticipated at its outset, destroy alternative medicine or even curtail its growth. There are some striking continuities with the nineteenth century, including the persistence of medical magnetism, though somnambulisme became an increasingly marginal phenomenon in the middle decades of the twentieth century, sustained for the most part by rural healers typically known as dormeuses. The diagnostic function of the somnambules was largely replaced by radiesthesia, a procedure akin to dowsing, in which a pendulum suspended over the patient's body is supposed to capture the magnetic emanations and reveal through its movements the harmony or disharmony of the internal organs. Spiritism also faded after the war of 1914-18, displaced by new forms of anti-materialist medicine, ${ }^{101}$ which nonetheless retained certain affinities with it. ${ }^{102}$ Just as striking are the new developments, most of which involved imports from central Europe, the US, and Asia: the remarkable growth of naturopathy and homoeopathy, which enjoyed a tremendous resurgence in the 1920s, though not on the same scale as in Germany; and the development of chiropractic, osteopathy, reflexotherapy, centrotherapy, iridodiagnosis, and acupuncture, among other forms of alternative medicine. ${ }^{103}$

Some of these movements, especially homoeopathy and naturopathy, attracted a following within the medical profession, and the interwar period saw the broader

\footnotetext{
${ }^{99}$ On the broader links between republicanism, positivism, and science in the late nineteenth century, see, for example, Claude Nicolet, L'Idée républicaine en France (1789-1924): essai d'histoire critique, Paris, Gallimard, 1982, p. 311 and passim.

${ }^{100}$ T Mouroux, Le Magnétisme et la justice française devant les droits de l'homme: mon procès, Angers, the author, 1901, pp. 66-8 and passim.

${ }^{101}$ See, for example, Charles Robert Richet, Traité de métapsychique, 2nd ed., Paris, Alcan, 1923.

${ }^{102}$ On popular somnambulisme, see Dr Émile Boismoreau, Coutumes médicales et superstitions populaires du bocage vendéen, Paris, Honoré
}

\author{
Champion, 1911, ch. 5, 'Dormeuses et \\ somnambules'. On radiesthesia: Albert Leprince, \\ Radiesthésie médicale: applications de l'art du \\ sourcier à la médecine humaine, Paris, Legrand, \\ 1936. \\ ${ }^{103}$ See, for example, Albert Leprince, \\ L'Acupuncture à la portée de tous: manuel théorique \\ et pratique de l'acupuncture chinoise et des \\ méthodes qui en dérivent, Paris, Éditions Dangles, \\ n.d.; idem, Traité de réflexothérapie, Paris, Maloine, \\ 1924; and idem, La Vertébrothérapie: subluxations \\ vertébrales et réflexes vertébraux, Paris, Maloine, \\ 1931.
}




\section{Matthew Ramsey}

development among medical insiders of several related currents of thought now generally subsumed under the label "medical holism", though the term was not used at the time. ${ }^{104}$ The holists' often divergent goals are less easily described than what they rejected: an official medicine based in the laboratory, which understood diseases as the products of encounters between invasive pathogens and the cells of the body, and whose therapeutics relied on specific countervailing measures based on this model. Holists responded by adopting some of the following positions: human life is not simply the product of elementary physical and chemical forces and cannot be fully apprehended using the methods of the natural sciences (Bergson's notions of vital force and intuition were an important influence in the early part of the century); the mind and the body with all its various parts constitute an integrated whole; the human organism cannot be understood apart from its physical and social environment; disease cannot be explained without carefully considering the underlying condition of the organism in which it appears (this emphasis on what holists called le terrain, which recalled older conceptions of the individual constitution or diathesis, owed much to recent developments in immunology). At times one can see links to a broader philosophical organicism and to a sociological tradition running from Comte to Durkheim that sought to create new forms of social organization for the individualist world that had emerged from the French Revolution, its disaggregative tendencies reinforced by the growth of vast impersonal cities and industrial empires. Holists drew more extensively, however, on the much older tradition of medicine based on individual constitutions and the environment, and many explicitly identified their approach as neo-Hippocratic.

The most distinctively French alternative medicine of the interwar period emerged in the 1930s within and outside the medical profession from the confluence of medical holism with the Catholic revival that produced Emmanuel Mounier's personalism and Jacques Maritain's integral humanism. ${ }^{105}$ Christian medical humanism sought less to promote faith or the miraculous per se than to create a medicine that would respect the dignity of the human person, in opposition to the perceived dehumanizing effects of biological reductionism. Lyons, which boasted a rich tradition of nonstandard medicine, was the great centre, with a prominent group led by René Biot, who had strong links to Carrel. The latter, by then based at the Rockefeller Institute in New York, contributed the most widely influential text, Man the unknown. ${ }^{106}$ Medical humanism led to a renewed emphasis within the profession on family medicine and the physician-patient relationship. ${ }^{107}$ But it also encouraged lay movements that de-emphasized official therapeutics.

\footnotetext{
${ }^{104}$ See the excellent collection of essays edited by Christopher Lawrence and George Weisz, Greater than the parts: holism in biomedicine, 1920-1950, New York and Oxford, Oxford University Press, 1998, esp. ch. 5, Weisz, 'A moment of synthesis: medical holism in France between the wars', pp. 68-93. The account that follows is based primarily on ch. 5. Thanks also to Weisz for his helpful comments and suggestions on this section and on the essay as a whole.

${ }^{105}$ Maritain, Humanisme intégral: problèmes temporels et spirituels d'une nouvelle chrétienté,
}

Paris, F Aubier, 1936; Mounier, Manifeste au service du personnalisme, Paris, Fernand Aubier/Éditions Montaigne, 1936.

${ }^{106}$ Man the unknown [L'Homme, cet inconnu], New York and London, Harper \& Brothers, 1935. French ed., Paris, Librairie Plon, 1935.

${ }^{107}$ Dolores Peters is currently working on this topic; see her unpublished paper, 'Catholic doctors and family medicine: confessional and professional interests in interwar France', conference on 'Medicine and the family', Society for the Social History of Medicine, University of Exeter, July 1994. 
For a more radical minority of laymen as well as a few physicians, Catholic medical humanism did not go far enough in its anti-materialism. Some turned to Rudolf Steiner's syncretistic anthroposophy, which joined elements of Western philosophical and religious traditions, including Christianity, to principles borrowed from Eastern traditions, such as reincarnation. Steiner denounced not science but scientism for having failed to recognize the central importance of spirit/soul to human life. ${ }^{108}$ One of his admirers, a member of the Francophile Brazilian intelligentsia, criticized Carrel at length in French for not having taken the necessary final step of recognizing the invisible world that shapes all reality. Even though Carrel rejected "artificial health" maintained by vaccines and serums and called for a "natural health" based on the tissues' capacity for resistance, he was still blinded by maya, "the illusion of the exclusive reality of the physical world". 109

The most influential medical anti-materialist in the Francophone world, however, was an antagonist of Steiner-Paul Carton, a practising physician in the Paris region who had many affinities with Catholic humanism, naturopathy, and neo-Hippocratism. He called his medical system la médecine naturiste and promoted his "Hippocratic-Cartonian method" but in the end adopted his own idiosyncratic form of spiritualism, which he dubbed occultism or occult science. ${ }^{110}$ His doctrine received a major boost in the 1940s from the best-selling novel by the Belgian writer Maxence van der Meersch, Bodies and souls (1943), ${ }^{111}$ whose protagonists are followers of Carton and treat official medicine with scepticism. It remained controversial, however, and Carton found himself accused of promoting medical nihilism, trafficking in old wives' remedies, and even of contributing to the death of Van der Meersch from tuberculosis. ${ }^{112}$ His complex views deserve an extended consideration, not because their content epitomizes French alternative medicine, even of the interwar period-no single system could be said to do so-but because they so fully exemplify the rich eclecticism, the interpenetration of science and spiritualism, and the crossing of boundaries by medical insiders that marked many of the most prominent forms of nonstandard medicine.

Carton characterized his approach as the integration of fundamental truths drawn from religion, philosophy, and medicine concerning human nature and man's place in the world. ${ }^{113}$ His preferred term for it was "synthetic naturism", and he devoted considerable

\footnotetext{
${ }^{108}$ See, for example, Steiner, The boundaries of natural science: eight lectures given in Dornach, Switzerland, September 27-October 3, 1920, Spring Valley (New York), Anthroposophic Press, 1983.

109 O-A Inglez de Sousa, L'Homme tel qu'on peut le connaître: réplique anthroposophique à "L'homme, cet inconnu" du Dr. Alexis Carrel, Geneva, Éditions Mongenet, 1950, p. 34.

${ }^{110}$ For sympathetic accounts of Carton's philosophy, see $\mathrm{M}^{\mathrm{gr}}$ Albert Bros, Le Docteur Paul Carton et son itinéraire spirituel, Paris, P Lethilleux, 1958, and Christopher Vasey, Le Message du $D^{r}$ Paul Carton: l'Hippocrate du XX $X^{e}$ siècle, Fillinges, Éditions Trois Fontaines, 1992.

111 Van der Meersch, Corps et âmes, roman ... ., 2 vols, Paris, Albin Michel, 1943; Bodies and souls, trans. Eithne Wilkins, London, Pilot Press, 1948. A play based on the novel was published in 1951, the year of the author's death: Corps et âmes, pièce
}

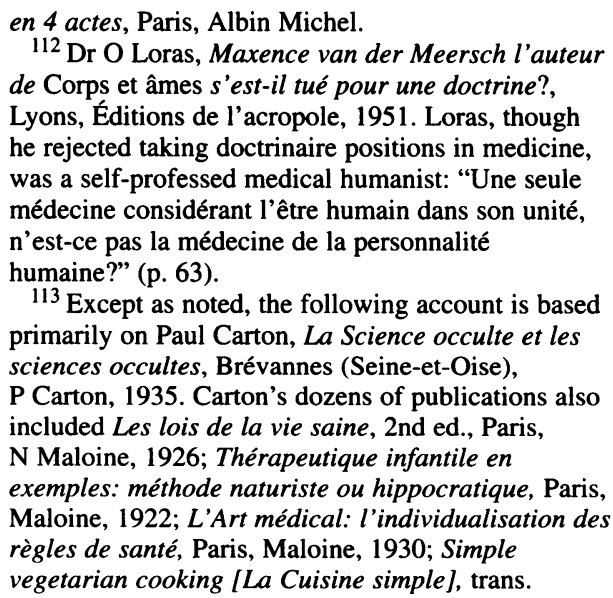
de Corps et âmes s'est-il tué pour une doctrine?, Lyons, Éditions de l'acropole, 1951. Loras, though he rejected taking doctrinaire positions in medicine, was a self-professed medical humanist: "Une seule médecine considérant l'être humain dans son unité, n'est-ce pas la médecine de la personnalité humaine?" (p. 63).

${ }^{113}$ Except as noted, the following account is based primarily on Paul Carton, La Science occulte et les sciences occultes, Brévannes (Seine-et-Oise), P Carton, 1935. Carton's dozens of publications also included Les lois de la vie saine, 2nd ed., Paris, N Maloine, 1926; Thérapeutique infantile en exemples: méthode naturiste ou hippocratique, Paris, Maloine, 1922; L'Art médical: l'individualisation des règles de santé, Paris, Maloine, 1930; Simple vegetarian cooking [La Cuisine simple], trans. 


\section{Matthew Ramsey}

energy to an indignant and ultimately fruitless campaign to reclaim the second word in the formula from its association with nudism. (He attributed what he saw as the perverted cult of the naked body chiefly to the baleful influence of Jean-Jacques Rousseau, "father of the radical nudists", though he gave Rousseau credit for his sceptical attitude toward the medicine of the doctors.) ${ }^{114}$ A large part of the programme involved spiritual reform and a return to morality and religion, which for Carton meant Roman Catholicism. This was not a feel-good spirituality; Carton believed in original sin and Hell, and a certain vision of Christian sacrifice was central to his world view and to his medicine. Carton also mixed in certain elements from the Hermetic tradition, and he sometimes characterized his medicine as a kind of white magic. He refused, however, to borrow from non-Western religious traditions.

To attain the truth, it was necessary to rise above the limits of conventional ways of thinking (l'état d'esprit primaire), a task Carton thought exceeded the powers of all but a cultivated elite; to try to popularize his esoteric "occult science" would be like casting pearls before swine. One had to begin by recognizing that twentieth-century positivists erred in at least three ways. They placed too much emphasis on conventional cause and effect ("second" causes), neglecting first causes and ultimately the Creator Himselfthough Carton also insisted that faith alone would not give us knowledge about the world. They failed to recognize that truth which is hidden because it is immaterial; the "occultism" that Carton promoted was meant to provide the needed "science of the invisible". 115 Scientific materialists, finally, much as they might scorn witches and magicians for pretending to have mastered the occult arts, in fact had much in common with them; all were the devil's henchmen.

The world described by Carton was suffused by immaterial forces, variously described as spirit, vitality, and magnetism. Each human being possessed, in addition to a material body, vital force and spirit; it was the last that determined the individual person or self. He also borrowed from theosophy the conception of an astral body, a subtler form of a physical body that normally inhabits it during its life but survives its death. Such views allowed him to accept paranormal phenomena as rare but real; lycanthropy might result from the "materialization of the astral body", and a haunted house from the "exteriorization of vital forces or astral bodies". The place of human beings in the universe was at the classic midpoint of the Great Chain of Being, cast in terms of a vaguely neoPlatonic dualism. "Man is at the intersection of two worlds: the higher one, the world of the spirit, and the lower one, the world of matter, or the world tout court. The human soul can rise toward the angelic soul and the divine soul, or descend toward the animal soul

Elizabeth Lucas, London, G G Harrap, 1931; Les Clefs du diagnostic de l'individualité: aide-mémoire de clinique thérapeutique naturiste, Paris, Le François, 1934. Some of his texts became hardy perennials of the alternative literature. See, for example, La Synthèse directrice et libératrice de la personne humaine: méthode hippocratiquecartonienne, 3rd ed., Paris, Le François, 1973; Le Décalogue de la santé, 9th ed., n.p., n.d., 1992; L'Art médical: l'individualisme des règles de santé, l'orientation sanitaire et professionnelle, la culture des immunités naturelles. Méthode hippocratiquecartonnienne, 3rd ed., Paris, Le François, 1965; Alimentation, hygiène et thérapeutique infantile en exemples . . , 6th ed., Abbeville, Imprimerie F Paillart, 1988.

${ }^{114}$ Idem, Le Faux Naturisme de Jean-Jacques Rousseau, Paris, Norbert Maloine, 1931, quotation on p. 79.

${ }_{115}$ Carton, La Science occulte, op. cit., note 113 above, p. 5 . 


\section{Alternative Medicine in Modern France}

and toward the abysses of the chaotic and diabolical worlds." The ultimate goal to which we must aspire is "sanctification through life that is less and less materialized and more and more spiritualized, to attain the life of perpetual communion [la vie unitive] with the divine Word, from which one has issued and to which one must return by making oneself the servant of the Law, through Sacrifice." Carton's belief in the pervasive manifestations of spirit helps explain, among other things, why he gave credence to graphology. A handwritten letter preserves "a vital and psychic potential which characterizes the person who wrote it." His doctrine of the primacy of spirit-death was merely the breaking of material bonds-also helps account for his aversion to a medicine that intervened aggressively to preserve the body, though he was far from being the therapeutic nihilist that some of his detractors suggested. ${ }^{116}$

Carton's quarrels with official medicine, like his entire $2 u v r e$, have to be understood simultaneously in philosophical, religious, and moral terms. "Classical medicine [by which Carton means the official medicine of the late nineteenth and twentieth centuries] is exclusively the science of corporeal matter and the cadaver"-the science of man in its limited form [la science primaire de l'homme]. Because it is uninformed by true occult science, it focuses exclusively on the mechanical operation of physical laws. It substitutes the laboratory for the clinical examination, and the specimen for the whole person, ignoring the importance of spirit and vitality, and the old Hippocratic teachings on the role of character, temperament, particular constitution, and environment. For Carton, as for many interwar holists, the resistance of le terrain was at least as important in explaining disease as the presence or absence of a germ that the microbiologist could see under the microscope. Le terrain could not be directly observed, and Carton had little use for X-rays, tests on body fluids and tissues, and the other diagnostic techniques of scientific medicine. The worst offences of laboratory medicine were those involving vivisection, which, in addition to being as ineffectual as all the others, profaned the sanctity of innocent life. Materialist medicine, with its blind determinism, also denied free will and ignored the place of man in the moral universe; like black magic, it led to "individual disorganization". It failed to recognize our responsibility for our own health and the need to respect the rules not just of hygiene but also of morality and religion. For Carton, diseases are "the repayment for errors that have been committed, sanctions for incorrect behaviour, crises of mental purification and organic cleansing, as well as opportunities for learning and sacrifice." 117

From this perspective, virtually all the armamentarium of official medicine seemed worthless or even dangerous and morally debilitating. Typically, like witchcraft, its therapies attempted to deal with the consequences of faulty conduct without addressing the underlying causes; like black magic, they produced only illusory results. Carton particularly condemned biological products-attenuated microbes, serums, blood transfusions, transplanted monkey glands. This perverted medicine recalled the toad venom, semen, menses, and animal sacrifice used in black magic. Where such remedies appeared to work, it was through "transfer", which violated the fundamental laws of morality and religion. Vaccines and serums made an innocent beast take on the burden of defence that rightly should fall on the patient himself; following the model of Jesus, he

${ }^{116}$ Quotations: ibid., pp. 344, 224, 250, 170,

${ }^{117}$ Quotations: ibid., pp. 414, 422. $225-6$. 


\section{Matthew Ramsey}

should make a personal sacrifice, rather than imitate the Jews, who employed animal sacrifice to avoid personal responsibility. (Carton, like many of his contemporaries, was reflexively but not obsessively anti-Semitic.) In any case, such a patient would only pay more heavily later on for his moral fault; so would an entire population protected, for example, by a vaccine against typhoid fever. It was not surprising, Carton suggested, that physicians' families seemed to have the most serious health problems, since they used materialist remedies most consistently and violated the laws of morality, as well as generally eating too much meat. Carton's own médecine naturiste emphasized regimen, to reinforce natural immunity, and right living according to the natural order and the laws ordained by God. He did also somehow find room for a few standard therapies, such as digitalis and diphtheria antiserum.

Carton's medicine, then, was powerfully counterhegemonic, and one might perhaps expect him to have made common cause with others fighting for medical freedom, but in his almost Manichaean world view the practitioners of virtually every recognized form of alternative medicine and the occult were as bad as or worse than the doctors-heretics and the active agents of diabolical forces. He fulminated against medical magnetism, spiritism, chiromancy, cartomancy, rhabdomancy, metapsychic practices (involving paranormal psychological phenomena such as telepathy), astrology (though he accepted that the stars influence human life), black magic, alchemy (though he accepted that base metals could be transmuted into gold), charms, philtres, spells, black masses, magic books like Le Grand Grimoire, Le Dragon rouge, and Les Clavicules de Salomon, together with nudism, tobacco, alcohol, and narcotics-all, in their way diabolical. So, too, with reflexotherapy, irido-diagnosis, radiesthesia, materialist homoeopathy-which was like a kind of vaccine-and acupuncture. These practices generally resembled witchcraft and black magic; many of those who used them were simply charlatans. Acupuncture also represented an act of "treason towards the white race". 118 Carton lashed out at modern bonesetters and healers, who were like the old witches, at false prophets, somnambules, magnetizers, psychics, and mediums who claimed to communicate with Napoleon, Voltaire, Joan of Arc, and Marie-Antoinette, at Papus and Éliphas Lévy (the abbé Louis Constant who became a prolific author of writings on the occult, which later influenced Papus), at the Rosicrucians, Free Masons, and Carbonari (a masonic offshoot of the radically democratic early-nineteenth-century secret society), at Phineas Parkhurst Quimby, Mary Baker Eddy and Christian Science, at Mme Blavatsky, Annie Besant and theosophy, at Rudolf Steiner and anthroposophy. Some of this last group were of some use as anti-materialists but ultimately deserved condemnation for being at times anti-Christian and invariably and especially anti-Catholic. On the secular and even materialist wing of unorthodoxy, Carton denounced phrenology, systems that emphasized the power of positive thinking and mental suggestion, which had led to all the horrors of Americanstyle advertising, the ethical culture movement, the new humanism, and above all hypnosis, psychotherapy, and Freudian psychoanalysis. The "lay confession" of psychoanalysis was a parody of Catholic confession; the appeal to the unconscious (whose reality Carton accepted) brought up sordid sexual obsessions, and far from freeing patients from "repression", left them completely unhinged.

118 Ibid., p. 345. 


\section{Alternative Medicine in Modern France}

Like much of alternative medicine in the strong sense, what we might call Cartonism had distinct political ramifications. Carton liked to claim that the honest expression of his convictions would lead both the Right and the Left to condemn him. Nearly all his views would have been anathema to the left-leaning intelligentsia of the Third Republic, but it is not hard to find at least some affinities with the anti-republican Right. Free Masonry came close to being an obsession with Carton, who cited with approval the work of the fiercely anti-masonic Robert Vallery-Radot. The hostilities of 1914-18, in this account, began with a shot fired in Sarajevo by the "Jewish teenager" Princip, and formally ended with the treaty imposed at Versailles by the notorious Masons Woodrow Wilson and Lloyd George "with the goal of establishing universal Democracy and the religion of humanity". It was no coincidence that the settlement "dismembered Catholic Austria-Hungary and respected the unity of Protestant Germany."119 Taking a longer perspective, much of what had gone wrong with Western civilization was the fault of Voltaire and Rousseau, as the old refrain had it, and especially of Jean-Jacques, who could be blamed not only for nudism but also for the spread of progressive education and the principle of popular sovereignty, two of Carton's other great bugbears.

Despite the idiosyncrasies of Cartonism, Carton's distaste for the medicine, philosophy and politics of the Third Republic points to a more fundamental transformation since the nineteenth century, when strong bonds had joined alternative medicine to important elements of the republican, democratic, and socialist Left. With the political centre redefined as the socially conservative democratic republic, and with an established Left committed to varieties of positivism or dialectical materialism, alternative medicine, when not politically neutral, has tended to be identified with the traditionalist Catholic Right and with the fringe Left-linked in some cases to the tradition of Christian democracy, with which the Church had at best an uneasy relationship. The Right briefly found a congenial home from 1940 to 1944 in the Vichy Regime, which had no monolithic ideology but consistently repudiated the sort of positivism associated with the secular schools and universities of the recently collapsed Third Republic. Alexis Carrel, still struggling with the fundamental questions of science, faith, and human identity, returned home to Marshal Pétain's France to head the French Foundation for the Study of Human Problems. Vichy conservatives, parting company with their more technocratic-minded colleagues in the administration, who welcomed the new French State as an opportunity for state-sponsored modernization free of interference from parliament, also called for returning to nature and the soil and renouncing the excesses of industrial civilization. A certain vision of health through correct living, which might be called Rousseauean had that name not been anathema to its proponents, pervaded these circles. The Right was Green before the Left. But just as the economic plans, social security programme, and other postwar statist measures of the Fourth Republic emerged from a consensus involving elements of Vichy and the Resistance, opposition to growth-oriented central planning, large-scale industrialism, and high-tech medicine has brought together an odd coalition of the vaguely anti-republican Right, including many who embrace integral Catholicism, and the vaguely neo-anarchist, anti-communist new Left, represented in the various Green movements and parties. For at least some participants in alternative medicine, like many of their

\footnotetext{
${ }^{119}$ Ibid., p. 396, citing Vallery-Radot, Le temps de la colère, Paris, B Grasset, 1932.
} 


\section{Matthew Ramsey}

nineteenth-century predecessors, official medicine remains part of a feared or hated establishment.

It was, however, the central planners who prevailed under Vichy, and then under the Fourth Republic. They were a significant factor in the extraordinarily rapid industrial and urban development of the postwar period, which profoundly transformed a society that had possessed the largest peasant sector of the major industrial countries. This process helped accelerate the integration into alternative medicine of practices long represented as the "folk" medicine of the peasantry-mainly phytotherapy using native rather than exotic plants. These forms of medicine had a very long pedigree, and there was nothing new in either their use by the urban middle classes or the notion that the good old herbal remedies somehow encapsulated the benefits of traditional country living. But mass promotion of the simple virtues and the virtue of simples attained an unprecedented scale and intensity, making full use of the electronic media and every other available form of publicity. Mességué, the son of a peasant healer from the Gers who became the star folk healer of mid-twentieth-century France, adroitly exploited this trend. He was an adept practitioner of radiesthesia, an energetic organizer and polemicist on behalf of la médecine libre, ${ }^{120}$ and a fluent and boastful self-promoter. He owed some of his notoriety to the galaxy of celebrities who came to him for a consultation or simply to discuss alternative medicine, including (he tells us) President Édouard Herriot, Admiral Darlan, Winston Churchill, Konrad Adenauer, King Farouk, and the entertainer Mistinguett. ${ }^{121}$ A crucial part of his appeal, however, derived from his fidelity to his father's herbal remedies and his claim to draw upon the wisdom of his peasant ancestors to avert or overcome the ills of modern civilization, whose anxious victims, unable to lead their lives at a natural pace, were doomed to the ills of the hurried and harried, from indigestion to ejaculation praecox. Modern biomedicine, though he always treated it publicly with deference and came to seek an alliance with it, was a part of that civilization.

\section{The Contemporary Scene: Awaiting the New Age?}

In present-day France, alternative medicine flourishes as never before, a phenomenon commonly associated in public discourse with growing acceptance of the supernatural, the occult, and the paranormal. As in many other industrialized societies, Max Weber's "disenchantment of the world" is seemingly being reversed. Polls suggest widespread and increasing belief in astrology, witchcraft, fortune-telling and parapsychological phenomena. Surveys also indicate that consultations with astrologers, dowsers, and unconventional healers are on the rise, as are other alternative forms of self-help. Rika Zarai's immensely popular books on natural medicine have been huge best-sellers, with sales numbering in the millions. ${ }^{122}$ In $1995,50,000$ taxpayers reported their occupation as astrologer, medium, healer, and the like, outnumbering France's fewer than 36,000 Roman Catholic priests and greatly outnumbering its 6,000 psychiatrists, two other occupations

\footnotetext{
${ }^{120}$ See, for example, Maurice Mességué, Pour les guérisseurs et la médecine libre, and Fernand Mouquin, Contre les guérisseurs et la médecine libre, Collection pour ou contre, Nancy, BergerLevrault, 1967.

${ }^{121}$ Maurice Mességué, Of men and plants: the
} autobiography of the world's most famous plant
healer, trans. Pamela Swinglehurst, London,
Weidenfeld and Nicolson, 1972.
122 See Zaraï, Ma médecine naturelle, [Paris],
Éditions de la Seine, 1989, and Ces émotions qui
guérissent, [Paris], Le Grand Livre du Mois, 1995. 


\section{Alternative Medicine in Modern France}

ministering to the distressed and anxious. Practitioners of these arts have become increasingly sophisticated in the marketing of their products, sometimes organizing commercial firms and advertising on the state-run Minitel videotex system. ${ }^{123}$ By the end of 1997 they had also become a major presence on the World Wide Web. ${ }^{124}$ Alternative medicine is an integral part of this larger trend. Indeed, a comparative study based on public opinion surveys carried out in seven European countries between 1985 and 1992 found the highest incidence of use in France ( 49 per cent), although, as the authors acknowledge, divergent polling methods and definitions of alternative medicine make these comparisons approximate at best. ${ }^{125}$

The report from the Ministry of Social Affairs on the different types of alternative medicine reveals many parallels with the US and the UK, including some direct imports from America and some indirect ones from Asia, but also several distinctive features. Far more than the United States, though far less than Germany, France has seen the development of anthroposophy as a medical system. New Age therapies and movements such as acupuncture, yoga, and Scientology have also won a growing number of converts. One sees here both the internationalization of the new alternative medicine and what the sociologist Françoise Bouchayer has called "the balkanization of medical heterodoxy", its fragmentation into hundreds of discrete mini-systems. ${ }^{126}$ The practitioners have organized themselves into a profusion of voluntary associations, such as the Société Française de Phyto-aromathérapie. Patients, however, are not necessarily loyal to any one movement, but mix and match the various forms of médecines douces, while continuing to use standard therapies. France has also been home to a spreading charismatic renewal movement both within and outside the Catholic Church. For the Church, it has given new legitimacy to religious healing and the struggle against secular rationalism; one effect has been an upsurge in cures reported at Lourdes. ${ }^{127}$

The most striking feature of the French scene, however, is the pervasive presence of homoeopathy, which experienced an extraordinary resurgence in the twentieth century and emerged as the most prominent of les médecines douces. France is the largest producer and consumer of homoeopathic remedies in the world. ${ }^{128}$ Homoeopathy enjoys a certain degree of sympathy in official medical circles, even among sceptics, many of whom consider its remedies at least less harmful than those employed by some other forms of alternative medicine. Indeed, the majority of homoeopathic products sold in pharmacies have been prescribed by a physician, though an important factor here is that the cost of prescription drugs can be reimbursed by social security. The homoeopathy movement aspires to more than this, actively seeking full scientific legitimation. One of the great causes célèbres of recent times in French biomedicine involved a series of dilution experiments conducted in 1988 at the immunopharmacology laboratory of Jacques

\footnotetext{
${ }^{123}$ Barry James, 'France possessed by the occult and irrational', Skeptical Inquirer, 1990, 14: 232-3 (reprinted from International Herald Tribune); Marlise Simons, 'France under the spell of Druids?', New York Times, 30 April 1996.

124 At the time of this writing a guide from the Annuaire des médecines douces could be found at: http://www.naturmed.com.

125 Peter Fisher and Adam Ward, 'Complementary
}

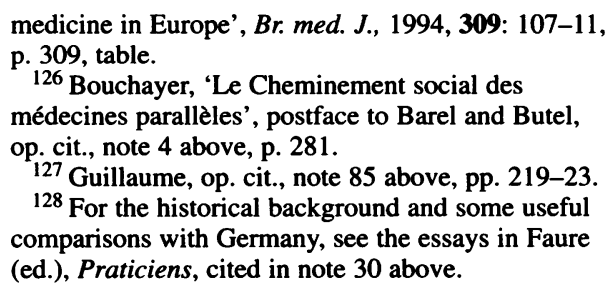

128 For the historical background and some useful comparisons with Germany, see the essays in Faure (ed.), Praticiens, cited in note 30 above. 


\section{Matthew Ramsey}

Benveniste at INSERM. Like a homoeopathic remedy, an antibody diluted with water to the vanishing point seemed to continue to produce its effect; somehow the water had retained a "memory" of it. Benveniste's study was published in Nature and then, in an extraordinary move, discredited there by the publication's own editors; his laboratory was closed at the end of $1993 .{ }^{129}$

To some extent, what is happening in medicine is another manifestation of the extraordinary explosion of consumer choice, comparable to recent developments in, say, the telecommunications industry. For some of the most visible alternative medical movements, however, acceptance involves more than the choice of a product and may, indeed, imply an indictment of the very society that made such a market possible, and of materialism in every sense of the term. Like their American and British counterparts, many alternative medical systems, even those that claim scientific legitimacy, share an opposition to materialist reductionism and aggressive technologies, whether medical or industrial. A spiritual dimension appears not only in religious healing but also in the energy force or "qi" exploited by acupuncture, yoga's attempt to integrate spirit and body, and the role of invisible and immaterial energy in homoeopathy. Anthroposophy holds that matter itself thinks, and that medicine can be based on non-material vital forces. New Age healing centres have emerged that to outsiders appear to resemble cults; an establishment at Vitry-aux-Loges in the forest of Orléans received widespread coverage on French television. ${ }^{130}$ In addition, a keen ecological consciousness informs several of these movements, notably homoeopathy, which typically presents itself as outside the industrial system of production and consumption. The appeal of such approaches as agni hostra/homa-therapy, which promises to heal the earth itself, is primarily ecological. As in the US, some believers-many of them alienated intellectuals and even health professionals-have withdrawn from mainstream society and formed utopian communes, which one sociologist labels "neo-rural apocalyptic communities". ${ }^{131}$ Here alternative medicine is but one part, though a crucial one, of a reaction against technology, modern civilization, and scientific rationalism. ${ }^{132}$ Alternative medicine is also linked in some cases to political dissent, on both the Left and the Right. Survey data reveal that both the Greens and members of the National Front are disproportionately represented among those who participate in alternative medical practices. What most clearly unites the political utopians at both ends of the political spectrum is their rejection of a status quo based on negotiations among what they see as unprincipled interest groups corrupted by the American-style consumer society.

As this essay has tried to suggest, a dialectical relationship exists between the public claims of official and alternative medicine. One effect of the efflorescence of

\footnotetext{
129 On the initial controversy, see Timothy $M$ Beardsley, 'Science and the citizen' column, Scientific American, September 1988, pp. 19-22; on subsequent developments, Tara Patel, "“Molecule memory" man to lose his laboratory', New Scientist, 23 October 1993, p. 10.

${ }^{130}$ Alan Riding, 'In the forest of Orléans, unneighborly snarls', New York Times, 10 February 1993.

${ }^{131}$ D Léger, 'From healing to salvation: the neorural apocalyptic communities in France', in Marc
}

Augé and Claudine Herzlich (eds), The meaning of illness: anthropology, history and sociology, trans. Katherine J Durnin, et al., Luxembourg, Harwood Academic Publishers, 1995, pp. 207-24.

132 Vasan V Paranjpe, 'Homa-thérapie: notre dernière chance': "La technologie a accompli son œuvre. Désormais nous sommes obligés de nous tourner vers la super technologie pour nous sortir du désastre que nous avons provoqué par la pollution généralisée. . . " (http://www.mygale.org/03/ agniyoga/agnipage.htm). 
counterhegemonic medicines, particularly those related to New Age movements, has been a renewal of the old Enlightenment discourse on popular errors and superstitions, though not on the same scale as in the US, where a vigorous anti-alternative medicine movement has developed pari passu with the alternative medicine renaissance. ${ }^{133}$ One representative French text is a book by Gilbert Carraz, biologist and former professor of pharmacology and dean of the faculty at Grenoble, on Médecines douces et charlatans. For Carraz, Zarai is an idiot and barely literate; Mességué, who at least can write correct French, is both naive and a charlatan. What Mességué and others call la médecine libre would constitute "an authorization for anyone at all to practice medicine and (why not?) to have the Social Security system cover diagnosis with a pendulum, the tisanes of Mme Zaraï, crippling manipulations by bonesetters, and the recipes of African sorcerers". ${ }^{134}$ More than rhetoric is involved. This being France, the state has intervened, not only against individual practitioners but also against sects and cults whose belief systems and practices often have an important medical component. The parliamentary report on sects published in January 1996 has led to an ambitious programme of propaganda and surveillance, with a coordinator of anti-sect efforts to be named in each region. ${ }^{135}$ Witness also the trial of Scientologists in Lyons in the autumn of 1996 on charges of swindling and involuntary homicide (the latter involving the suicide of a disciple)-less ferocious than the German anti-Scientology campaign, but part of a more broadly based effort. ${ }^{136}$ Both the government and the national council of the Ordre des Médecins have come down hard on the group known as Invitation à la Vie, which uses the "harmonization of energies" to treat disease. Physicians associated with the movement have been expelled from the Order, and one was placed under investigation for involuntary manslaughter. ${ }^{137}$

There seems little prospect in the near future for a major liberalization of the French regulatory regime that keeps alternative practitioners in the status of medical outsiders. Although the European Union, in keeping with the guarantees on freedom of movement contained in the Treaty of Rome, has worked to standardize medical credentials, the question of alternative medicine remains unresolved; the European Court, supporting the position of the Council of Ministers and the European Commission, has ruled that member states may or may not require a licence for medical practice and may or may not choose to recognize alternative medical occupations. The drive for a uniform convention favourable to alternative medicine has come from Paul Lannoye, a Green member of the European Parliament from Belgium, who would like to see far-reaching reforms: common standards and training; the integration of alternative medicine into official medical

\footnotetext{
${ }^{133}$ A well-funded voluntary organization known as the National Council Against Health Fraud, which describes itself as a consumer advocacy group, has been active since 1984 . The very militant Quackwatch, Inc., assumed its present name in 1997 but has been in operation since the 1970s; it has a French-language Web site based in Canada, http://www.allerg.qc.ca/quackwf.html. The US is also the home base of the Committee for the Scientific Investigation of Claims of the Paranormal and its journal, the Skeptical Inquirer, which for two decades have maintained a steady campaign against "antiscientific" claims, many of them related to
}

health and medicine; an affiliated journal, The Scientific Review of Alternative Medicine, was launched in October 1997.

${ }^{134}$ Carraz, Médecines douces et charlatans, Grenoble, Éditions Glénat, 1988, pp. 78-9.

135 'Rapport français fait au nom de la Commission d'enquête sur les sectes', http://www.geocities.com/ CapitolHill/3329/rapportf.htm. See H T, 'Un "Moniteur sectes" va être nommé dans chaque région', Le Monde, 3 October 1996.

${ }^{136}$ Le Monde, 5, 9, and 10 October 1996.

${ }^{137}$ Le Figaro, 31 May 1997. 
institutions-but with professional autonomy for practitioners with complete systems; a place for alternative medicines in the European pharmacopoeia, after careful assessment through controlled clinical trials; and guaranteed reimbursement by social security. Ultimately the boundaries between official and alternative would be erased. A resolution to this effect, dating from 1994, encountered some opposition in committee and ultimately failed to win passage; the Parliament contented itself in 1997 with approving additional funds for evaluating nonstandard remedies and for further study of the larger question of the place of alternative medicine in the European Union. ${ }^{138}$ The international framework for research has been provided by a voluntary cooperative project within the framework of "COST" (Cooperation in the field of Science and Technology). 139

So France clings to what many think of as its Napoleonic heritage while eagerly embracing medical pluralism: this is the paradoxical pattern whose roots this essay set out to uncover. Once we recognize the crucial role of medical insiders in certain forms of nonstandard medicine, above all homoeopathy, the phenomenon seems less puzzling. It is not intrinsically inconsistent to accept the dominance of official medicine in the sense of a highly trained medical profession and its legally recognized institutions while rejecting exclusive reliance on official medicine in the sense of the current standard practices and theories. Yet this is only one aspect of the problem, since so much alternative medicine in France, as elsewhere, has been in the hands of medical outsiders.

One obvious-and largely justified-response would be that certain human behaviours are notoriously refractory, and that regulatory or prohibitory legislation cannot be expected to reduce their incidence substantially. The search for relief from disease and suffering is surely one of those behaviours, as the traditional discourse on quackery and popular medical errors almost always noted. But this quest is socially and culturally conditioned, and the question of national differences is one that deserves further exploration. In the French case, one might start by considering relations with authority. Bureaucratic restrictions engender strategies to get around them; a history of French taxation that was not also a history of tax evasion would be seriously incomplete. In France getting around the rules has been elevated to a kind of art form; it is known as le système $D$ (for le système débrouille, in the more polite formulation), which, as the sociologist Laurence Wylie wrote in a classic discussion, "consists of any devious and usually ill-defined means by which an individual can take initiative in spite of the restrictions imposed on him by society." 140 One could perhaps also make a stronger claim, which is that certain alternative practices may persist not just despite but also because of

\footnotetext{
138 European Parliament, Bulletin UE 5-1997, 1.3.40, 'Résolution du Parlement européen sur le statut des médecines non conventionnelles', and $\mathrm{Br}$ med. J., vol. 314, no. 7095, 7 June 1997. See also Tom Huggon and Alan Trench, 'Brussels post-1992: protector or persecutor?', in Saks (ed.), op. cit., note 25 above, pp. 241-9, and, on the history of regulation of the professions in the EU, Louis $\mathrm{H}$ Orzack, 'Educators, practitioners and politicians in the European Common Market', Higher Education, 1980, 9: 307-23.

139 'Memorandum of understanding for the implementation of a European research project on
}

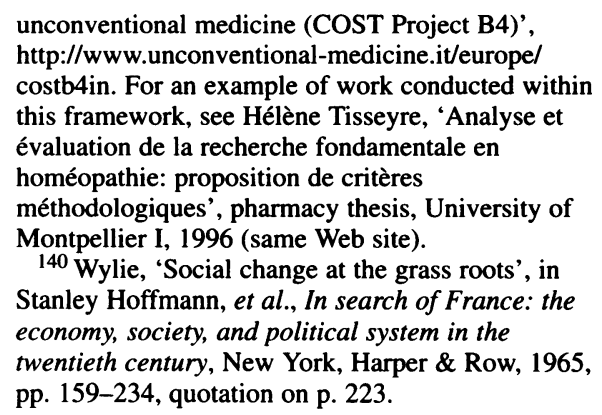
http://www.unconventional-medicine.it/europe/ costb4in. For an example of work conducted within this framework, see Hélène Tisseyre, 'Analyse et évaluation de la recherche fondamentale en homéopathie: proposition de critères méthodologiques', pharmacy thesis, University of Montpellier I, 1996 (same Web site).

140 Wylie, 'Social change at the grass roots', in Stanley Hoffmann, et al., In search of France: the economy, society, and political system in the twentieth century, New York, Harper \& Row, 1965, pp. 159-234, quotation on p. 223. 


\section{Alternative Medicine in Modern France}

official hostility, or at least that their counterhegemonic intensity derives from their deviant status. Without the Ordre des Médecins, Mességué would still have been a highly successful entrepreneur, but he would not have been, for some, a kind of folk hero. Students of French society and politics have often noted the association between bureaucratic rigidity in la société bloquée $e^{141}$ and the periodic eruption of discontent, from the chahut that throws a classroom into chaos to large-scale public demonstrations and violent challenges to governmental authority. Full-blown medical rebellions are almost unheard of, though feelings have run quite high at the trials of healers with large and loyal followings. The forces are too unbalanced, the most highly motivated actors are sick individuals more immediately interested in seeking treatment than justice, and the great majority of the population-whether or not they consult alternative practitioners-have invested too heavily in biomedicine and the modern health care system to wish to bring it down. But just as-to borrow the oft-quoted insight of the anthropologist James Scott $^{142}$ - the authority of ruling elites is more often contested through "everyday resistance" than fully-fledged insurrection, the authority of the state-sponsored medical elite is challenged through small acts of defiance.

In addition to this complex relationship with authority and bureaucracy, French culture has been marked by a love-hate relationship with science and technology, apparent in debates over environmental issues as well as health and medicine, ${ }^{143}$ and in the profoundly conflicted attitude toward America as symbol of modernity. ${ }^{144}$ This ambivalence, too, has deep historical roots in a society torn between the impulse to modernize and resistance to change. France has staked its future on nuclear energy; ${ }^{145}$ it also clings to its peasant past, if only through its rituals - the annual August holiday exodus, for example, which takes many to the countryside to commune with the soil-and perhaps also in its use of alternative medicine.

Some of these patterns are distinctively French. But the resurgence of interest in alternative medicine is also, of course, part of a much broader cultural phenomenon in the industrialized world, in this fin de siècle which is also the fin du millénaire. The claims of scientific medicine are counterbalanced by a recognition of the pathologies of a consumer society, the stubborn presence of both old and new infectious disease, particularly AIDS, and the sheer cost of providing increasingly expensive medical technology to the population at large-even the famously generous French social security system faces significant cuts. For many, hope comes not from the promise of further technical advances worthy of the new millennium, but from a shift of direction, from a sense of redressing the balance: holistic medicine, correct living, spiritual renewal, return to Nature, or a new science less rigidly bound by the old paradigms.

\footnotetext{
${ }^{141}$ Michel Crozier, La Société bloquée, Paris, Éditions du Seuil, 1970; The stalled society, New York, Viking, 1973.

142 James C Scott, Weapons of the weak: everyday forms of peasant resistance, New Haven, Yale University Press, 1985.

${ }^{143}$ See Michael D Bess, 'Ecology and artifice: shifting perceptions of nature and high technology in postwar France', Technology and Culture, 1995, 36: $830-62$.
}

\footnotetext{
144 Richard F Kuisel, Seducing the French: the dilemma of Americanization, Berkeley and Los Angeles, University of California Press, 1993.

${ }^{145} \mathrm{On}$ the historical background, see Gabrielle Hecht, The radiance of France: nuclear power and national identity after World War II, Cambridge, Mass., MIT Press, 1998.
} 


\section{Matthew Ramsey}

Alternative medicine in the strong sense began rather than ended with the rise of academic medicine to hegemonic status; its importance has paradoxically increased rather than declined with the advance of biomedicine; and its fortuna is best understood not in purely medical but also in cultural and to some extent political terms, as part of a contest over defining humanity's place in the world. Medicine attracts such intense attention and provokes such animated debates not only because as a practical matter health is so central to our well-being, but also because medicine makes a profound statement about who and what we are. It is a debate we can expect to continue and intensify. A biomedicine that deconstructs human nature gives rise to its dialectical opposite. Although historians are notoriously averse to offering predictions, this essay will end with one, which is that the completion of the Human Genome Project will have as its concomitant an alternative medicine of unprecedented metaphysical militancy, in France and elsewhere. 